University of Nebraska - Lincoln

DigitalCommons@University of Nebraska - Lincoln

2010

\title{
A continuous measure of gross primary production for the conterminous United States derived from MODIS and AmeriFlux data
}

Jingfeng Xiao

Purdue University, j.xiao@unh.edu

Qianlai Zhuang

Purdue University, qzhuang@purdue.edu

Beverly E. Law

Oregon State University, bev.law@oregonstate.edu

Jiquan Chen

University of Toledo, jiquan.chen@utoledo.edu

Pennis D. Baldogehi University of California - Berkeley, baldocchi@berkeley.edu

Part of the Natural Resources and Conservation Commons

See next page for additional authors

Xiao, Jingfeng; Zhuang, Qianlai; Law, Beverly E.; Chen, Jiquan; Baldocchi, Dennis D.; Cook, David R.; Oren, Ram; Richardson, Andrew D.; Wharton, Sonia; Ma, Siyan; Martin, Timothy A.; Verma, Shashi; Suyker, Andrew E.; Scott, Russell L.; Monson, Russell K.; Litvak, Marcy; Hollinger, David Y.; Sun, Ge; Davis, Kenneth J.; Bolstad, Paul; Burns, Sean; Curtis, Peter S.; Drake, Bert G.; Falk, Matthias; Fischer, Marc L.; Foster, David R.; Gu, Lianhong; Hadley, Julian L.; Katul, Gabriel G.; Matamala, Roser; McNulty, Steve; Meyers, Tilden P.; Munger, J. William; Noormets, Asko; Oechel, Walter; Tha Paw U, Kyaw; Schmid, Hans Peter; Starr, Gregory; Torn, Margaret S.; and Wofsy, Steven C., "A continuous measure of gross primary production for the conterminous United States derived from MODIS and AmeriFlux data" (2010). Papers in Natural Resources. 359.

https://digitalcommons.unl.edu/natrespapers/359

This Article is brought to you for free and open access by the Natural Resources, School of at DigitalCommons@University of Nebraska - Lincoln. It has been accepted for inclusion in Papers in Natural Resources by an authorized administrator of DigitalCommons@University of Nebraska - Lincoln. 


\section{Authors}

Jingfeng Xiao, Qianlai Zhuang, Beverly E. Law, Jiquan Chen, Dennis D. Baldocchi, David R. Cook, Ram Oren, Andrew D. Richardson, Sonia Wharton, Siyan Ma, Timothy A. Martin, Shashi Verma, Andrew E. Suyker, Russell L. Scott, Russell K. Monson, Marcy Litvak, David Y. Hollinger, Ge Sun, Kenneth J. Davis, Paul Bolstad, Sean Burns, Peter S. Curtis, Bert G. Drake, Matthias Falk, Marc L. Fischer, David R. Foster, Lianhong Gu, Julian L. Hadley, Gabriel G. Katul, Roser Matamala, Steve McNulty, Tilden P. Meyers, J. William Munger, Asko Noormets, Walter Oechel, Kyaw Tha Paw U, Hans Peter Schmid, Gregory Starr, Margaret S. Torn, and Steven C. Wofsy 


\title{
A continuous measure of gross primary production for the conterminous United States derived from MODIS and AmeriFlux data
}

\author{
Jingfeng Xiao ${ }^{\mathrm{a}, *}$, Qianlai Zhuang ${ }^{\mathrm{b}}$, Beverly E. Law ${ }^{\mathrm{c}}$, Jiquan Chen ${ }^{\mathrm{d}}$, Dennis D. Baldocchi ${ }^{\mathrm{e}}$, David R. Cook ${ }^{\mathrm{f}}$, \\ Ram Oren ${ }^{\mathrm{g}}$, Andrew D. Richardson ${ }^{\mathrm{h}}$, Sonia Wharton ${ }^{\mathrm{i}}$, Siyan Ma ${ }^{\mathrm{e}}$, Timothy A. Martin ${ }^{\mathrm{j}}$, Shashi B. Verma ${ }^{\mathrm{k}}$, \\ Andrew E. Suyker ${ }^{\mathrm{k}}$, Russell L. Scott ${ }^{1}$, Russell K. Monson ${ }^{\mathrm{m}}$, Marcy Litvak ${ }^{\mathrm{n}}$, David Y. Hollinger ${ }^{\mathrm{O}}$, Ge Sun ${ }^{\mathrm{p}}$, \\ Kenneth J. Davis ${ }^{\mathrm{q}}$, Paul V. Bolstad ${ }^{\mathrm{r}}$, Sean P. Burns ${ }^{\mathrm{m}}$, Peter S. Curtis ${ }^{\mathrm{s}}$, Bert G. Drake ${ }^{\mathrm{t}}$, Matthias Falk ${ }^{\mathrm{i}}$,
} Marc L. Fischer ${ }^{\mathrm{u}}$, David R. Foster ${ }^{\mathrm{v}}$, Lianhong Gu ${ }^{\mathrm{w}}$, Julian L. Hadley ${ }^{\mathrm{x}}$, Gabriel G. Katul ${ }^{\mathrm{g}}$, Roser Matamala ${ }^{\mathrm{y}}$, Steve McNulty ${ }^{\mathrm{p}}$, Tilden P. Meyers ${ }^{\mathrm{z}}$, J. William Munger ${ }^{\mathrm{a} a}$, Asko Noormets ${ }^{\mathrm{ab}}$, Walter C. Oechel ${ }^{\mathrm{ac}}$, Kyaw Tha Paw $U^{i}$, Hans Peter Schmid ${ }^{\text {ad,ae }}$, Gregory Starr ${ }^{\text {af }}$, Margaret S. Torn ${ }^{\text {ag }}$, Steven C. Wofsy ${ }^{\text {ah }}$

a Department of Earth \& Atmospheric Sciences, Purdue Climate Change Research Center, Purdue University, West Lafayette, IN 47907, USA

${ }^{\mathrm{b}}$ Department of Earth \& Atmospheric Sciences, Department of Agronomy, Purdue Climate Change Research Center, Purdue University, West Lafayette, IN 47907, USA

c College of Forestry, Oregon State University, Corvallis, OR 97331, USA

' Department of Environmental Sciences, University of Toledo, Toledo, OH 43606, USA

e Ecosystem Science Division, Department of Environmental Science, Policy and Management, University of California, Berkeley, Berkeley, CA 94720, USA

f Argonne National Laboratory, Environmental Science Division, Argonne, IL 60439, USA

g Nicholas School of the Environment, Duke University, Durham, NC 27708, USA

${ }^{\mathrm{h}}$ Department of Organismic and Evolutionary Biology, Harvard University, Cambridge, MA 02138, USA

${ }^{i}$ Department of Land, Air and Water Resources, University of California, Davis, Davis, CA 95616, USA

${ }^{\mathrm{j}}$ School of Forest Resources E Conservation, University of Florida, Gainesville, FL 32611, USA

k School of Natural Resources, University of Nebraska-Lincoln, Lincoln, NE 68583, USA

${ }^{1}$ USDA-ARS Southwest Watershed Research Center, Tucson, AZ 85719, USA

${ }^{\mathrm{m}}$ Department of Ecology and Evolutionary Biology, University of Colorado, Boulder, CO 80309, USA

${ }^{\mathrm{n}}$ Department of Biology, University of New Mexico, Albuquerque, NM 87131, USA

${ }^{\circ}$ USDA Forest Service, Northeastern Research Station, Durham, NH 03824, USA

${ }^{\mathrm{p}}$ USDA Forest Service, Southern Research Station, Raleigh, NC 27606, USA

q Complex Systems Research Center, University of New Hampshire, Durham, NH 03824

${ }^{\mathrm{r}}$ Department of Forest Resources, University of Minnesota, St. Paul, MN 55108, USA

${ }^{s}$ Department of Evolution, Ecology, and Organismal Biology, Ohio State University, Columbus, OH 43210, USA

${ }^{\mathrm{t}}$ Smithsonian Environmental Research Center, Edgewater, MD 21037, USA

u Lawrence Berkeley National Laboratory, Environmental Energy Technologies Division, Atmospheric Science Department, Berkeley, CA 94720, USA

${ }^{v}$ Harvard Forest and Department of Organismic and Evolutionary Biology, Harvard University, Petersham, MA 01366, USA

w Oak Ridge National Laboratory Environmental Sciences Division, Oak Ridge, TN 37831, USA

${ }^{x}$ Harvard Forest, Harvard University, Petersham, MA 01366, USA

${ }^{y}$ Argonne National Laboratory, Biosciences Division, Argonne, IL 60439, USA

${ }^{\mathrm{z}}$ NOAA/ARL, Atmospheric Turbulence and Diffusion Division, Oak Ridge, TN 37831, USA

aa Department of Earth and Planetary Sciences, Harvard University, Cambridge, MA 02138, USA

ab Department of Forestry and Environmental Resources and Southern Global Change Program, North Carolina State University, Raleigh, NC 27695, USA

ac Department of Biology, San Diego State University, San Diego, CA 92182, USA

${ }^{\text {ad }}$ Department of Geography, Indiana University, Bloomington, IN 47405, USA

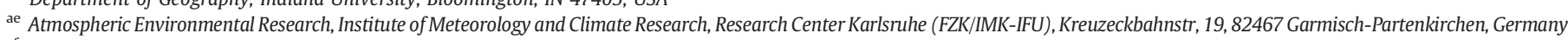

af Department of Biological Sciences, University of Alabama, Tuscaloosa, AL 35487, USA

ag Lawrence Berkeley National Laboratory, Earth Science Division, Berkeley, CA 94720, USA

ah Division of Engineering and Applied Science/Department of Earth and Planetary Science, Harvard University, Cambridge, MA 02138, USA

\section{A R T I C L E I N F O}

\section{Article history:}

Received 28 January 2009

Received in revised form 8 October 2009

Accepted 24 October 2009

\section{A B S T R A C T}

The quantification of carbon fluxes between the terrestrial biosphere and the atmosphere is of scientific importance and also relevant to climate-policy making. Eddy covariance flux towers provide continuous measurements of ecosystem-level exchange of carbon dioxide spanning diurnal, synoptic, seasonal, and interannual time scales. However, these measurements only represent the fluxes at the scale of the tower footprint. Here we used remotely sensed data from the Moderate Resolution Imaging Spectroradiometer

\footnotetext{
* Corresponding author. Now at Department of Meteorology, Pennsylvania State University, University Park, PA 16802, USA.

E-mail address: j.xiao@unh.edu (J. Xiao).
} 
Keywords:

Gross primary productivity

MODIS

AmeriFlux

Eddy covariance

Regression tree

US

Carbon fluxes

Interannual variability

Satellite data

Biomes
(MODIS) to upscale gross primary productivity (GPP) data from eddy covariance flux towers to the continental scale. We first combined GPP and MODIS data for 42 AmeriFlux towers encompassing a wide range of ecosystem and climate types to develop a predictive GPP model using a regression tree approach. The predictive model was trained using observed GPP over the period 2000-2004, and was validated using observed GPP over the period 2005-2006 and leave-one-out cross-validation. Our model predicted GPP fairly well at the site level. We then used the model to estimate GPP for each $1 \mathrm{~km} \times 1 \mathrm{~km}$ cell across the U.S. for each 8-day interval over the period from February 2000 to December 2006 using MODIS data. Our GPP estimates provide a spatially and temporally continuous measure of gross primary production for the U.S. that is a highly constrained by eddy covariance flux data. Our study demonstrated that our empirical approach is effective for upscaling eddy flux GPP data to the continental scale and producing continuous GPP estimates across multiple biomes. With these estimates, we then examined the patterns, magnitude, and interannual variability of GPP. We estimated a gross carbon uptake between 6.91 and $7.33 \mathrm{Pg} \mathrm{C} \mathrm{yr}^{-1} \mathrm{for}^{-}$ the conterminous U.S. Drought, fires, and hurricanes reduced annual GPP at regional scales and could have a significant impact on the U.S. net ecosystem carbon exchange. The sources of the interannual variability of U.S. GPP were dominated by these extreme climate events and disturbances.

(C) 2009 Elsevier Inc. All rights reserved.

\section{Introduction}

The quantification of ecosystem carbon fluxes for regions, continents, or the globe can improve our understanding of the feedbacks between the terrestrial biosphere and the atmosphere in the context of global change and facilitate climate-policy decisions (Law et al., 2006). Gross primary productivity (GPP) is the amount of carbon fixed by vegetation through photosynthesis and a key component of ecosystem carbon fluxes and the carbon balance between the biosphere and the atmosphere (Mäkelä et al., 2008). The accurate estimation of GPP is essential for the quantification of net ecosystem carbon exchange (NEE) as the latter is often a small difference of two large carbon fluxes - GPP and ecosystem respiration $\left(R_{\mathrm{e}}\right)$. The estimation of GPP for regions, continents, or the globe, however, can only be made by using ecosystem models (e.g., Prince \& Goward, 1995) and/or remotely sensed data (e.g., Running et al., 2004).

Eddy covariance flux towers have been providing continuous measurements of ecosystem-level exchange of carbon, water, and energy spanning diurnal, synoptic, seasonal, and interannual time scales since the early 1990s (Baldocchi et al., 2001; Wofsy et al., 1993). At present, over 500 eddy covariance flux towers are operating on a longterm and continuous basis around the world (FLUXNET, http://daac. ornl.gov/FLUXNET). This global network encompasses a large range of climate and biome types (Baldocchi et al., 2001), and provides probably the best estimates of ecosystem-level carbon fluxes. The flux towers directly measure NEE that can be separated into two major components: GPP and $R_{\mathrm{e}}$ (Desai et al., 2008; Reichstein et al., 2005). However, these estimates only represent fluxes at the scale of the tower footprint with longitudinal dimensions ranging between a hundred meters and several kilometers depending on homogeneous vegetation and fetch (Göckede et al., 2008; Schmid, 1994). To quantify the exchange of $\mathrm{CO}_{2}$ between the terrestrial biosphere and the atmosphere, significant efforts are needed to upscale flux tower measurements from the stand scale to landscape, regional, continental, or global scales.

Satellite remote sensing is a potentially valuable tool for upscaling efforts (Running et al., 1999; Xiao et al., 2008). Several studies have integrated flux data with remote sensing data to quantify GPP over large areas. Zhang et al. (2007) estimated GPP for the Northern Great Plains grasslands using satellite and flux tower data. Yang et al. (2007) linked satellite observations to flux tower GPP data for the estimation of GPP for two broad vegetation types in the U.S. using a machine learning approach. Despite these efforts, to our knowledge, no study has upscaled AmeriFlux GPP data to the continental scale to produce spatially-explicit estimates of GPP across multiple biomes and to examine the patterns, magnitude, and interannual variability of GPP over the conterminous U.S.

Here we used a regression tree approach and remotely sensed data from the Moderate Resolution Imaging Spectroradiometer (MODIS) to upscale flux tower GPP data to the continental scale and produced wallto-wall GPP estimates for multiple biomes across the conterminous U.S. First, we developed a predictive GPP model based on site-specific MODIS and flux tower GPP data, and validated the model using eddy flux data in both temporal and spatial domains. Second, we applied the model to estimate GPP for each $1 \mathrm{~km} \times 1 \mathrm{~km}$ cell across the conterminous U.S. for each 8-day interval over the period 2000-2006 using wall-to-wall MODIS data. Third, we examined the patterns, magnitude, and interannual variability of GPP across the conterminous U.S.

\section{Data and methods}

\subsection{Regression tree approach}

We used a modified regression tree approach implemented in the commercial software, Cubist, to upscale flux tower GPP to the continental scale. Regression tree algorithms typically predict class membership by recursively partitioning a dataset into more homogeneous subsets. The partitioning process splits each parent node into two child nodes, and each child node is treated as a potential parent node. Regression tree models can account for a nonlinear relationship between predictive and target variables and allow both continuous and discrete variables. Previous studies showed that regression tree methods are not only more effective than simple techniques including multivariate linear regression, but also easier to understand than neural networks (e.g., Huang \& Townshend, 2003).

Cubist constructs an unconventional type of regression tree, in which the terminal nodes or leaves are linear regression models instead of discrete values (Minasny \& McBratney, 2008). Cubist produces rule-based models containing one or more rules, each of which is a set of conditions associated with a multivariate linear submodel. Cubist is a powerful tool for generating rule-based predictive models. A Cubist model resembles a piecewise linear model, except that the rules can overlap with one another (RuleQuest, 2008). Details on regression tree approaches and Cubist were described in Yang et al. (2003), Wylie et al. (2007), and Xiao et al. (2008). In our previous study, we used Cubist to develop a predictive NEE model and upscaled NEE estimates to the continental scale for the conterminous U.S. (Xiao et al., 2008). In this study, we used Cubist to construct a predictive GPP model based on MODIS and AmeriFlux GPP data. Cubist uses three statistical measures to evaluate the quality of the constructed predictive model, including mean absolute error (MAE), relative error (RE), and product-moment correlation coefficient (Xiao et al., 2008; Yang et al., 2003). MAE is calculated as:

$M A E=\frac{1}{N} \sum_{i=1}^{N}\left|y_{i}-\hat{y}_{i}\right|$ 
where $N$ is the number of samples used to establish the predictive model, and $y_{i}$ and $\hat{y}_{i}$ are the actual and predicted values of the response variable, respectively. $\mathrm{RE}$ is calculated as:

$R E=\frac{M A E_{T}}{M A E_{\mu}}$

where $M A E_{T}$ is the MAE of the constructed model, and $M A E_{\mu}$ is the MAE that would result from always predicting the mean value. All three statistical measures were used to evaluate the performance of the constructed model.

\subsection{Explanatory variables}

GPP is influenced by a variety of physical, physiological, atmospheric, hydrological, and edaphic variables. At the leaf level, GPP is influenced by several factors, including incoming solar radiation, air temperature, vapor pressure deficit, soil moisture, and nitrogen availability (Clark et al., 1999, 2004; Ruimy et al., 1995). At the canopy or ecosystem level, GPP is also influenced by leaf area index (LAI) (Ruimy et al., 1995) and canopy phenology (Richardson et al., 2009). At the stand or regional level, GPP is significantly affected by disturbances such as fire and harvest (Law et al., 2004). Many of these factors can be effectively assessed by satellite remote sensing. Surface reflectance depends on vegetation type, biophysical properties (e.g., biomass, leaf area, and stand age), soil background, soil moisture conditions, and sun-object- sensor geometry (Penuelas et al., 1993; Ranson et al., 1985; Schmidt \& Skidmore, 2003). Vegetation indices including normalized difference vegetating index (NDVI) and enhanced vegetation index (EVI) are closely correlated to the fraction of photosynthetically active radiation (fPAR; Asrar et al., 1984) absorbed by vegetation canopies, and are also related to vegetation biomass and fractional vegetation cover (e.g., Chen et al., 2004; Myneni et al., 2001; Persson et al., 1993; Tucker et al., 1985). Compared to NDVI, EVI is more responsive to canopy structural variations, such as LAI, canopy type, plant physiognomy, and canopy architecture (Gao et al., 2000). The normalized difference water index (NDWI; Gao, 1996) was shown to be strongly correlated with leaf water content (Jackson et al., 2004) and soil moisture (Fensholt \& Sandholt, 2003) over time. LAI and fPAR characterize vegetation canopy functioning and energy absorption capacity (Myneni et al., 2002) and are key parameters in most ecosystem productivity and biogeochemical models (Sellers et al., 1997). We therefore selected surface reflectance, EVI, LST, LAI, fPAR, and NDWI as explanatory variables. All of these variables were derived from MODIS data, which also avoided the complications and difficulties to merge disparate data sources (Xiao et al., 2008).

\subsection{AmeriFlux data}

We obtained the following three types of data: GPP from eddy covariance flux towers, explanatory variables derived from MODIS, and a land-cover map. The AmeriFlux network coordinates regional analysis

Table 1

Site descriptions including name, latitude, longitude, vegetation type, years of data available, and references for each flux site.

\begin{tabular}{|c|c|c|c|c|c|c|}
\hline Site & State & Lat & Lon & Vegetation type & Year & References \\
\hline Audubon Research Ranch (ARR) & $\mathrm{AZ}$ & 31.59 & -110.51 & Grasslands & 2002-2006 & \\
\hline Santa Rita Mesquite (SRM) & $\mathrm{AZ}$ & 31.82 & -110.87 & Savannas & 2004-2006 & Scott et al. (2009) \\
\hline Walnut Gulch Kendall Grasslands (WGK) & $\mathrm{AZ}$ & 31.74 & -109.94 & Grasslands & 2004-2006 & \\
\hline Sky Oaks Old Stand (SOO) & CA & 33.37 & -116.62 & Shrublands & 2004-2006 & Lipson et al. (2005) \\
\hline Sky Oaks Young stand (SOY) & CA & 33.38 & -116.62 & Shrublands & 2001-2006 & Lipson et al. (2005) \\
\hline Tonzi Ranch (TR) & $\mathrm{CA}$ & 38.43 & -120.97 & Savannas & 2001-2006 & Ma et al. (2007) \\
\hline Vaira Ranch (VR) & CA & 38.41 & -120.95 & Grasslands & 2001-2006 & $\mathrm{Xu}$ and Baldocchi (2004) \\
\hline Niwot Ridge Forest (NRF) & $\mathrm{CO}$ & 40.03 & -105.55 & Evergreen forests & 2000-2003 & Monson et al. (2002) \\
\hline Kennedy Space Center - Scrub Oak (KSC) & $\mathrm{FL}$ & 28.61 & -80.67 & Shrublands & 2000-2006 & Dore et al. (2003) \\
\hline Austin Cary - Slash Pine (AC) & FL & 29.74 & -82.22 & Evergreen forests & 2001-2005 & Powell et al. (2008) \\
\hline Bondville (Bon) & IL & 40.01 & -88.29 & Croplands & 2001-2006 & Hollinger et al. (2005) \\
\hline FNAL agricultural site (FAg) & IL & 41.86 & -88.22 & Croplands & 2005-2006 & \\
\hline FNAL Prairie site (FPr) & IL & 41.84 & -88.24 & Grasslands & 2004-2006 & \\
\hline Morgan Monroe State Forest (MMS) & IN & 39.32 & -86.41 & Deciduous forests & $2000-2005$ & Schmid et al. (2000) \\
\hline Harvard Forest EMS Tower (HFE) & MA & 42.54 & -72.17 & Deciduous forests & 2000-2004 & Urbanski et al. (2007) \\
\hline Harvard Forest Hemlock Site (HFH) & MA & 42.54 & -72.18 & Evergreen forests & 2004 & \\
\hline Little Prospect Hill (LPH) & MA & 42.54 & -72.18 & Deciduous forests & 2002-2005 & \\
\hline Howland forest (HF) & ME & 45.20 & -68.74 & Evergreen forests & 2000-2004 & Hollinger et al. $(1999,2004)$ \\
\hline Howland forest (west tower) (HFW) & ME & 45.21 & -68.75 & Deciduous forests & 2000-2004 & Hollinger et al. $(1999,2004)$ \\
\hline Sylvania Wilderness Area (SWA) & MI & 46.24 & -89.35 & Mixed forests & $2002-2006$ & Desai et al. (2005) \\
\hline Univ. of Mich. Biological Station (UMB) & MI & 45.56 & -84.71 & Mixed forests & $2000-2003$ & Gough et al. (2008) \\
\hline Missouri Ozark (MO) & MO & 38.74 & -92.20 & Deciduous forests & 2004-2006 & Gu et al. $(2006,2007)$ \\
\hline Goodwin Creek (GC) & MS & 34.25 & -89.97 & Grasslands & 2002-2006 & \\
\hline Fort Peck (FPe) & MT & 48.31 & -105.10 & Grasslands & 2000-2006 & \\
\hline Duke Forest loblolly pine (DFP) & NC & 35.98 & -79.09 & Evergreen forests & 2001-2005 & Oren et al. $(1998,2006)$ \\
\hline Duke Forest hardwoods (DFH) & $\mathrm{NC}$ & 35.97 & -79.10 & Deciduous forests & 2003-2005 & Pataki and Oren (2003) \\
\hline North Carolina loblolly pine (NCP) & $\mathrm{NC}$ & 35.80 & -76.67 & Evergreen forests & 2005-2006 & \\
\hline Mead irrigated continuous maize site (MIC) & $\mathrm{NE}$ & 41.17 & -96.48 & Croplands & 2001-2005 & Verma et al. (2005) \\
\hline Mead irrigated rotation (MIR) & $\mathrm{NE}$ & 41.16 & -96.47 & Croplands & 2001-2005 & Verma et al. (2005) \\
\hline Mead rainfed (MR) & $\mathrm{NE}$ & 41.18 & -96.44 & Croplands & 2001-2005 & Verma et al. (2005) \\
\hline Bartlett Experimental Forest (BEF) & $\mathrm{NH}$ & 44.06 & -71.29 & Deciduous forests & 2004-2005 & Jenkins et al. (2007) \\
\hline Toledo Oak Openings (TOO) & $\mathrm{OH}$ & 41.55 & -83.84 & Savannas & 2004-2005 & Noormets et al. (2008b) \\
\hline ARM Oklahoma (ARM) & $\mathrm{OK}$ & 36.61 & -97.49 & Croplands & 2003-2006 & \\
\hline Metolius intermediate aged ponderosa pine (MI) & OR & 44.45 & -121.56 & Evergreen forests & 2003-2005 & Irvine et al. (2007); Law et al.(2003) \\
\hline Metolius new young pine (MN) & OR & 44.32 & -121.61 & Evergreen forests & 2004-2005 & Irvine et al. (2007); Law et al. (2003) \\
\hline Brookings (Bro) & SD & 44.35 & -96.84 & Grasslands & 2004-2006 & \\
\hline Freeman Ranch Mesquite Juniper (FRM) & $\mathrm{TX}$ & 29.95 & -98.00 & Savannas & 2004-2006 & \\
\hline Wind River Crane Site (WRC) & WA & 45.82 & -121.95 & Evergreen forests & 2000-2004 & Falk et al. (2008) \\
\hline Lost Creek (LC) & WI & 46.08 & -89.98 & Deciduous forests & $2000-2005$ & \\
\hline Willow Creek (WC) & WI & 45.81 & -90.08 & Deciduous forests & $2000-2006$ & Cook et al. (2004) \\
\hline Wisconsin intermediate hardwood (WIH) & WI & 46.73 & -91.23 & Deciduous forests & 2003 & Noormets et al. (2008a) \\
\hline Wisconsin mature red pine (MRP) & WI & 46.74 & -91.17 & Evergreen forests & 2002-2005 & Noormets et al. (2007) \\
\hline
\end{tabular}


of observations from eddy covariance flux towers across North America, Central America, and South America (Law, 2006). We obtained the Level 4 data product for 42 AmeriFlux sites over the period 2000-2006 from the AmeriFlux website (http://public.ornl.gov/ameriflux) (Table 1). This product includes NEE data from most of the active flux sites in the network. These sites are distributed across the conterminous U.S. and cover a range of vegetation types: forests, shrublands, savannas, grasslands, and croplands. Moreover, the distribution of these sites in the mean annual climate space indicates that the sites we selected are fairly representative of typical U.S. climate types (Xiao et al., 2008). In addition, some of the forested sites (e.g., Austin Cary, FL; Metolius new young pine, OR; Metolius intermediate aged ponderosa pine, OR; Wisconsin intermediate hardwood, WI) are at different stages since stand replacing disturbance, which are located in disturbance clusters of sites. In addition, some of the sites have received treatment, including the Howland Forest West Tower (ME; nitrogen fertilizer) and the Mead cropland sites (NE; irrigation versus rainfed, continuous maize versus maize/soybean rotation). We therefore believe that these sites are fairly representative of typical U.S. ecosystem and climate types.

The Level 4 product consists of two types of GPP data, including standardized (GPP_st) and original (GPP_or) GPP. GPP was calculated from NEE and ecosystem respiration $\left(R_{\mathrm{e}}\right)$ :

$G P P_{-} s t=R_{e}-N E E_{-} s t$

and

GPP_or $=R_{e}-N E E_{-}$or

where NEE_st and NEE_or are standardized and original NEE, respectively. NEE_st was calculated using the storage obtained from the discrete approach (single point on the top of the tower) with the same approach for all the sites, whereas NEE_or was calculated using the storage sent by the principal investigators that can be obtained with the discrete approach or using a vertical $\mathrm{CO}_{2}$ profile system. Both NEE_st and NEE_or were gap-filled using the Marginal Distribution Sampling (MDS) method (Reichstein et al., 2005) and the Artificial Neural Network (ANN) method (Papale \& Valentini, 2003). The ANN method was generally, if only slightly, superior to the MDS method (Moffat et al., 2007). A number of methods are available for estimating
GPP. Although Stoy et al. (2006) showed that the non-rectangular hyperbolic method (Gilmanov et al., 2003) produces estimates more consistent with independent data, we chose to use a method that relies on gap-filled nighttime data because it is more frequently used and less computationally demanding. We used GPP calculated from NEE data that was gap-filled using the ANN method. For each site, if the percentage of the remaining missing values for GPP_st was lower than that for GPP_or, we selected GPP_or; otherwise, we used GPP_st. GPP_st was the first choice so that the processing procedure for GPP was the same for as many sites as possible. We used 8-day average GPP data $\left(\mathrm{g} \mathrm{C} \mathrm{m}^{-2}\right.$ day $\left.^{-1}\right)$ to match the compositing intervals of MODIS data.

\subsection{MODIS data}

We used the following four MODIS data products (Collection 4), including surface reflectance (MOD09A1; Vermote \& Vermeulen, 1999), daytime and nighttime LST (MOD11A2; Wan et al., 2002), EVI (MOD13A1; Huete et al., 2002), and LAI/fPAR (MOD15A2; Myneni et al., 2002). Surface reflectance and EVI are at a spatial resolution of $500 \mathrm{~m}$, while LST, LAI, and fPAR are at spatial resolution of $1 \mathrm{~km}$. Surface reflectance, LST, LAI, and fPAR are at a temporal resolution of 8 days, while EVI is at a temporal resolution of 16 days. Sims et al. (2005) showed that the midday values of gross $\mathrm{CO}_{2}$ exchange during satellite overpasses can be used to estimate 8-day mean gross $\mathrm{CO}_{2}$ exchange, bridging the connection between continuous measurements of flux tower data and 8-day MODIS data. We used the 16-day EVI product instead of EVI calculated from 8-day surface reflectance despite the lower temporal resolution of the 16-day EVI product. Each 16-day EVI composite was composited from 16 daily observations (Huete et al., 2002). The VI algorithm applies a filter to the data based on quality, cloud, and viewing geometry, and only the higher quality, cloud-free, filtered data are retained for compositing; the maximum value composite (MVC) method employed selects the observation with the highest VI value to represent the composting period (16 days) (Huete et al., 2002). MVC minimizes the contamination of clouds and aerosols and the effects of sensor view angles on VI (Hoblen, 1986). For the 8-day surface reflectance product, each pixel contains the best possible daily observation during an 8-day period as (a)

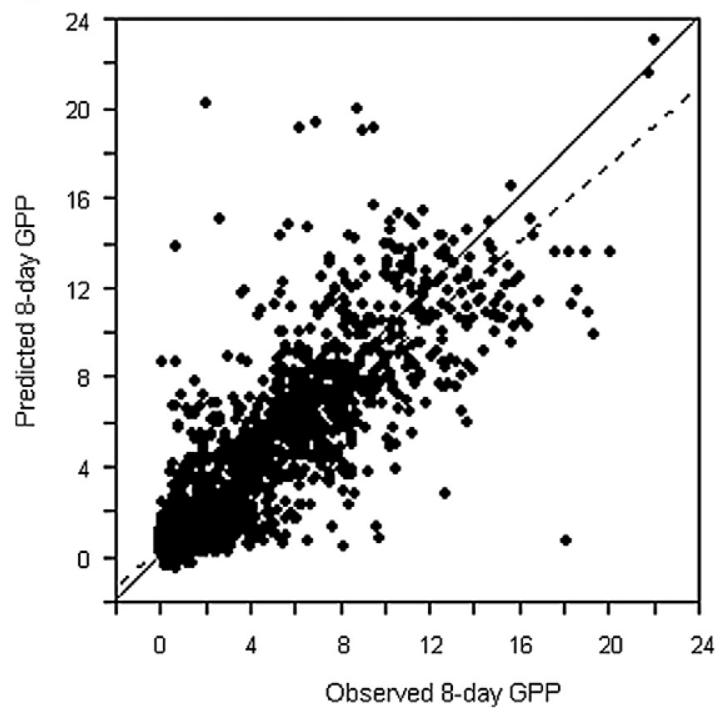

(b)

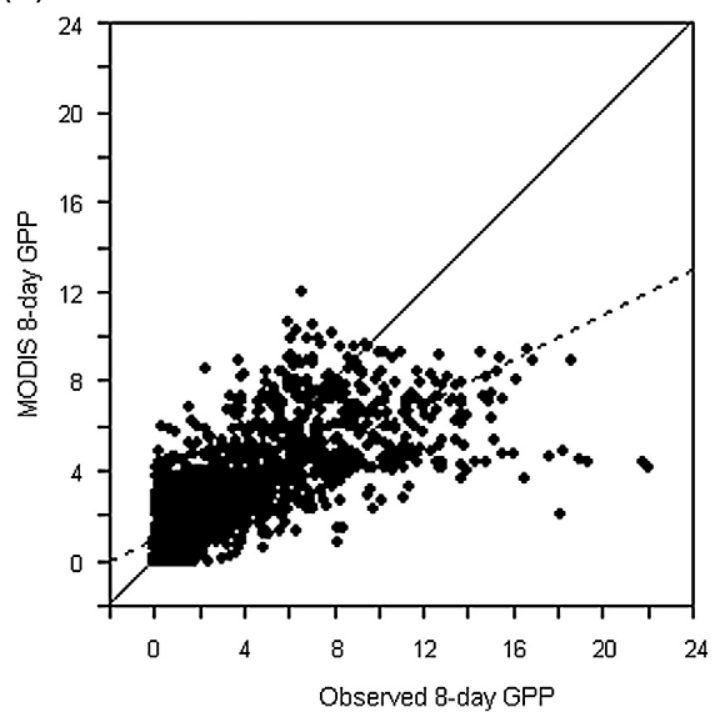

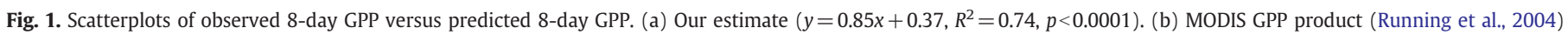
$\left(y=0.50 x+1.01, R^{2}=0.58, p<0.0001\right)$. For each plot, the solid line is the 1:1 line, and the dashed line is the regression line. 
selected on the basis of high observation coverage, low view angle, the absence of clouds or cloud show, and aerosol loading (Vermote \& Kotchenova, 2008), and the EVI calculated from the 8-day surface reflectance is less representative of the composting period than the MODIS EVI product.

For each AmeriFlux site, we obtained MODIS ASCII (American Standard Code for Information Interchange) subsets (Collection 4) consisting of $7 \mathrm{~km} \times 7 \mathrm{~km}$ regions centered on the flux tower, including surface reflectance, daytime and nighttime LST, EVI, LAI, and fPAR over the period 2000-2006 from the Oak Ridge National Laboratory's Distributed Active Archive Center (ORNL DAAC, 2006). We extracted average values for the central $3 \mathrm{~km} \times 3 \mathrm{~km}$ area within the $7 \mathrm{~km} \times 7 \mathrm{~km}$ cutouts to better represent the flux tower footprint
(Rahman et al., 2005; Schmid, 2002; Xiao et al., 2008). For each variable, we determined the quality of the value of each pixel within the area using the quality assurance (QA) flags included in the product. At each time step, we averaged the values of each variable using the pixels with good quality within the area to represent the values at the flux site. If none of the values within the $3 \times 3 \mathrm{~km}$ area were of good quality, we treated the period as missing. Each 16-day EVI value was used for the two 8-day intervals corresponding with the compositing interval of other MODIS data products. NDWI was calculated from band 2 and band 6 of the surface reflectance product.

To estimate GPP at the continental scale, we obtained wall-to-wall MODIS data including surface reflectance, daytime and nighttime LST,
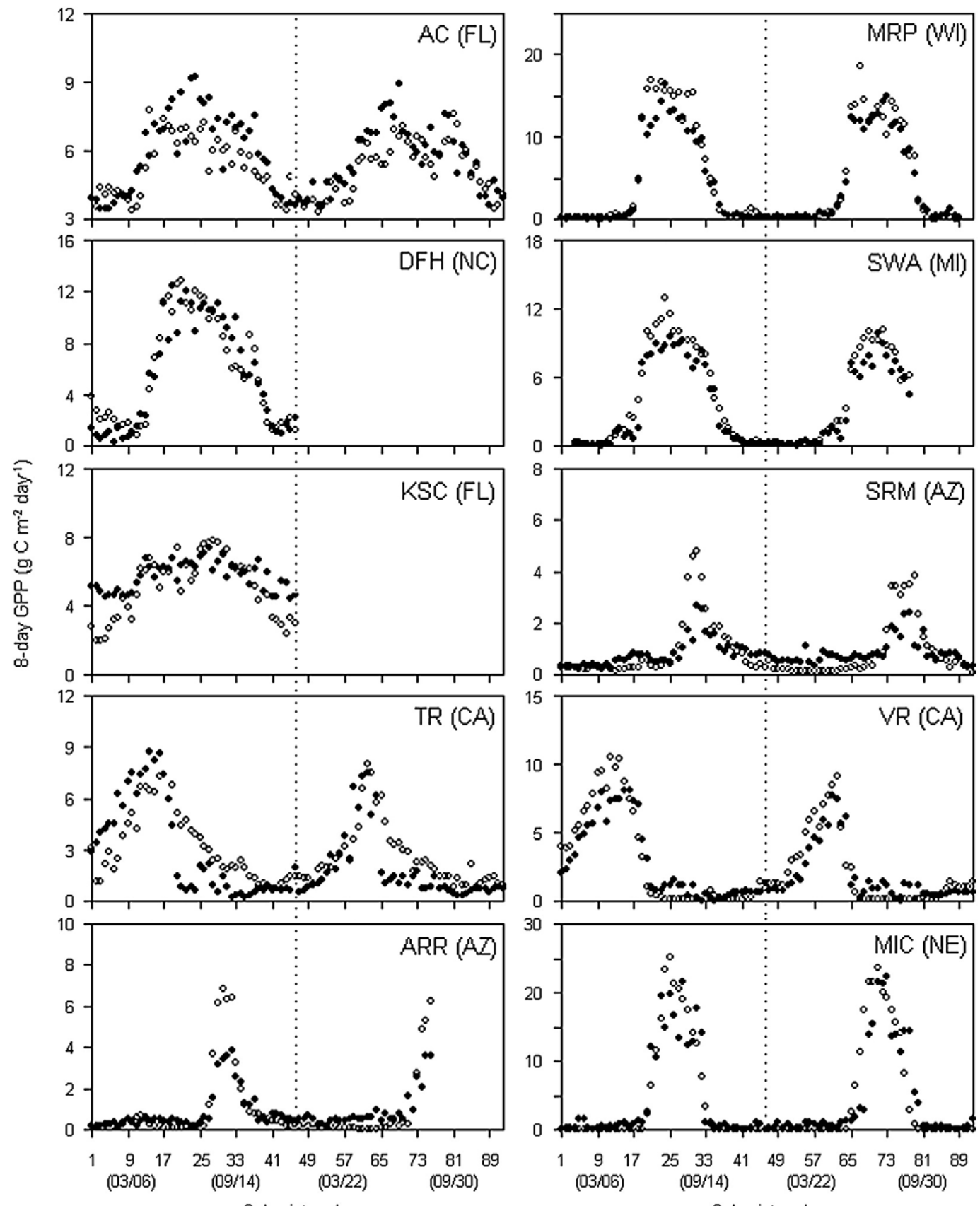

8-day interval

8-day interval

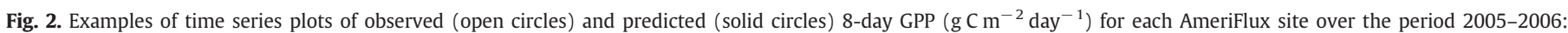

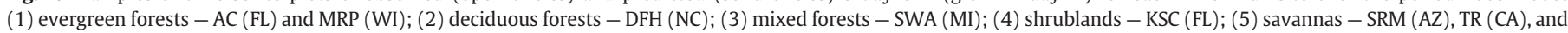

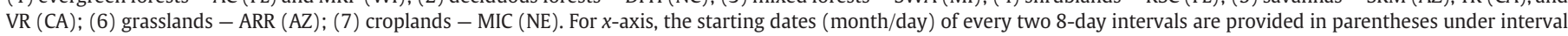
numbers. Dashed lines are used to separate 2005 from 2006. Site abbreviations are used here, and their full names are given in Table 1. 
LAI, and EVI over the period from February 2000 to December 2006 from the Earth Observing System (EOS) Data Gateway. For each variable, we determined the quality of the value of each pixel using the QA flags and replaced the bad-quality value using a linear interpolation approach (Zhao et al., 2005). The NDWI was calculated from band 2 (nearinfrared, 841-876 nm) and band 6 (shortwave infrared, 1628$1652 \mathrm{~nm}$ ) of the surface reflectance product (MOD09A1). Similarly, each 16-day EVI composite was used for two 8-day intervals corresponding to the compositing interval of other MODIS products. NDWI was calculated from band 2 and band 6 of the surface reflectance product for each 8-day interval.

We also used the MODIS 8-day GPP product (MOD17A2; Running et al., 2004) for comparison purposes at both the site level and the continental scale. The MODIS GPP product is at a spatial resolution of $1 \mathrm{~km}$, and a temporal resolution of 8 days. We obtained MODIS ASCII subsets (Collection 4) for the MODIS 8-day GPP product over the period 2005-2006 from the Oak Ridge National Laboratory's Distributed Active Archive Center (ORNL DAAC, 2006). We also obtained the MODIS annual GPP product (MOD17A3; Running et al., 2004) for 2005 from the Numerical Terradynamic Simulation Group, University of Montana (http://www.ntsg.umt.edu).

\subsection{Land cover}

To construct a predictive GPP model, we obtained the land-cover type for each AmeriFlux site based on the site descriptions (Table 1) and categorized each site into a class of the UMD (University of Maryland) land-cover classification system. Although the 42 AmeriFlux sites used in this study cover a variety of vegetation classes of this classification system, some classes (e.g., deciduous needleleaf forests, open shrublands) were not covered by any site. We therefore reclassified all vegetation classes of the UMD classification system to seven broader classes : evergreen forests (EF), deciduous forests (DF), mixed forests (MF), shrublands (Sh), savannas (Sa), grasslands ( $\mathrm{Gr}$ ), and croplands (Cr), following Xiao et al. (2008). Specifically, evergreen needleleaf forests and evergreen broadleaf forests were merged to evergreen forests, deciduous needleleaf forests and deciduous broadleaf forests to deciduous forests, closed shrublands and open shrublands to shrublands, and woody savannas and savannas to savannas.

To estimate GPP for each $1 \mathrm{~km} \times 1 \mathrm{~km}$ pixel across the conterminous U.S., we obtained the land-cover type for each pixel from the MODIS land-over map with the UMD classification system (Friedl et al., 2002). Similarly, we reclassified the vegetation classes of the MODIS land-cover map to the seven broader classes. We then used the reclassified landcover map to specify the land cover of each $1 \mathrm{~km} \times 1 \mathrm{~km}$ cell across the conterminous U.S.

\subsection{Model development}

We developed a predictive GPP model using Cubist based on the sitespecific MODIS and AmeriFlux GPP data. Our explanatory variables included land cover, surface reflectance (bands 1-7), daytime and nighttime LST, EVI, NDWI, fPAR, and LAI, and our response variable was $\operatorname{GPP}\left(\mathrm{g} \mathrm{C} \mathrm{m}^{-2}\right.$ day $\left.^{-1}\right)$. Land cover was included as a categorical variable in the model. We split the site-level data set of AmeriFlux and MODIS data into a training set (2000-2004) and a test set (2005-2006). If a site only had GPP observations for the period 2000-2004, the site was only included in the training set; if a site only had GPP observations for the period 20052006, the site was only included in the test set; otherwise, the site was included in both training and test sets. The training and test sets included 40 and 34 AmeriFlux sites, respectively. We had a total of 4529 and 2240 data samples for the training and test sets, respectively. In addition to the full model that includes all of the 14 independent variables, we also developed a series of models by dropping one or more variables at a time using Cubist. To select the best model, we evaluated the performance of each model based on MAE, RE, and correlation coefficient. We chose the model with the minimal MAE and RE and maximum correlation coefficient as the best model. We also evaluated the model performance using the Root Mean Squared Error (RMSE), scatterplots of predicted GPP versus observed GPP, and seasonal variations between the predicted and observed GPP.

We also evaluated the performance of our model in the spatial domain using leave-one-out cross-validation. In this approach, the data from a single site was used for validation, and the data from the remaining sites were used for training. The training and validation data were from different sites and were therefore independent from each other as these sites are generally hundreds of kilometers away from each other and the spatial autocorrelation between these sites was negligible. The leave-one-out cross-validation was conducted for each site, separately.

\subsection{Continental-scale estimation of GPP}

As mentioned earlier, the AmeriFlux sites used in this study are fairly representative of typical U.S. ecosystem and climate types. We believe that the predictive GPP model constructed from the 42 sites can be extrapolated to the conterminous U.S. We used the model to estimate GPP for each $1 \mathrm{~km} \times 1 \mathrm{~km}$ cell across the conterminous U.S. for each 8-day interval over the period 2000-2006 using wall-to-wall MODIS data. GPP was not estimated for non-vegetated cells (e.g., urban, barren), and water bodies. We compared our estimate with the MODIS GPP product (MOD17A3; Running et al., 2004). With our 8-day GPP estimates, we examined the patterns, magnitude, and interannual variability of GPP.

\section{Results and discussion}

\subsection{Model development}

\subsubsection{Predictive GPP model}

We chose the model containing five explanatory variables - land cover, EVI, daytime LST, LAI, and NDWI as the best model to predict

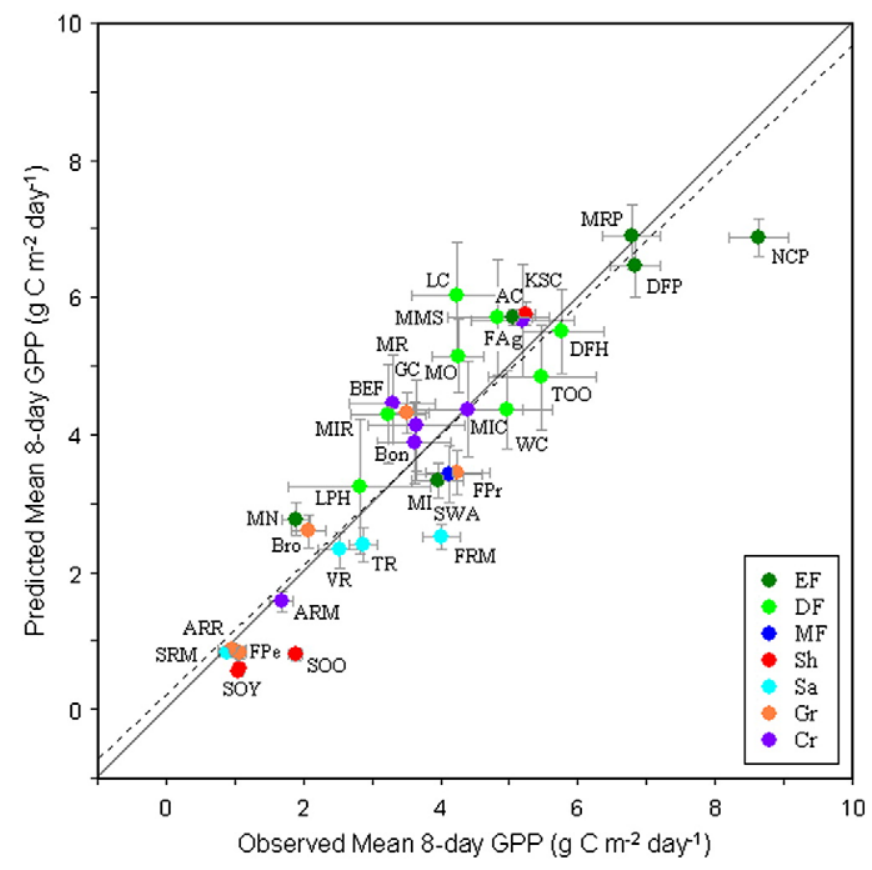

Fig. 3. Scatterplot of observed mean 8-day GPP versus predicted mean 8-day GPP across the Ameriflux sites. Error bars are standard errors (defined as the standard deviation divided by the square root of the number of observations) of the observed and predicted 8-day mean GPP. The solid line indicates the 1:1 line, and the dashed line indicates the regression line $\left(y=0.95 * x+0.21, R^{2}=0.84, p<0.0001\right)$. Site abbreviations are used here, and their full names are given in Table 1. 
GPP at the continental scale $\left(\mathrm{RE}=0.38, \mathrm{MAE}=1.22 \mathrm{~g} \mathrm{C} \mathrm{m}^{-2}\right.$ day $^{-1}$, $R^{2}=0.74$; Fig. $1 \mathrm{a}$ ). The performance of the model was comparable to that of the full model $\left(\mathrm{RE}=0.37, \mathrm{MAE}=1.19 \mathrm{~g} \mathrm{C} \mathrm{m}^{-2}\right.$ day $^{-1}$, $R^{2}=0.74$ ). Having only five explanatory variables could substantially reduce the computational complexity for continental-scale predictions compared to the full model. The predictive model consisted of five committee models, each of which was made of a number of rulebased submodels. For instance, the first committee model was made of the following 23 rule-based submodels:
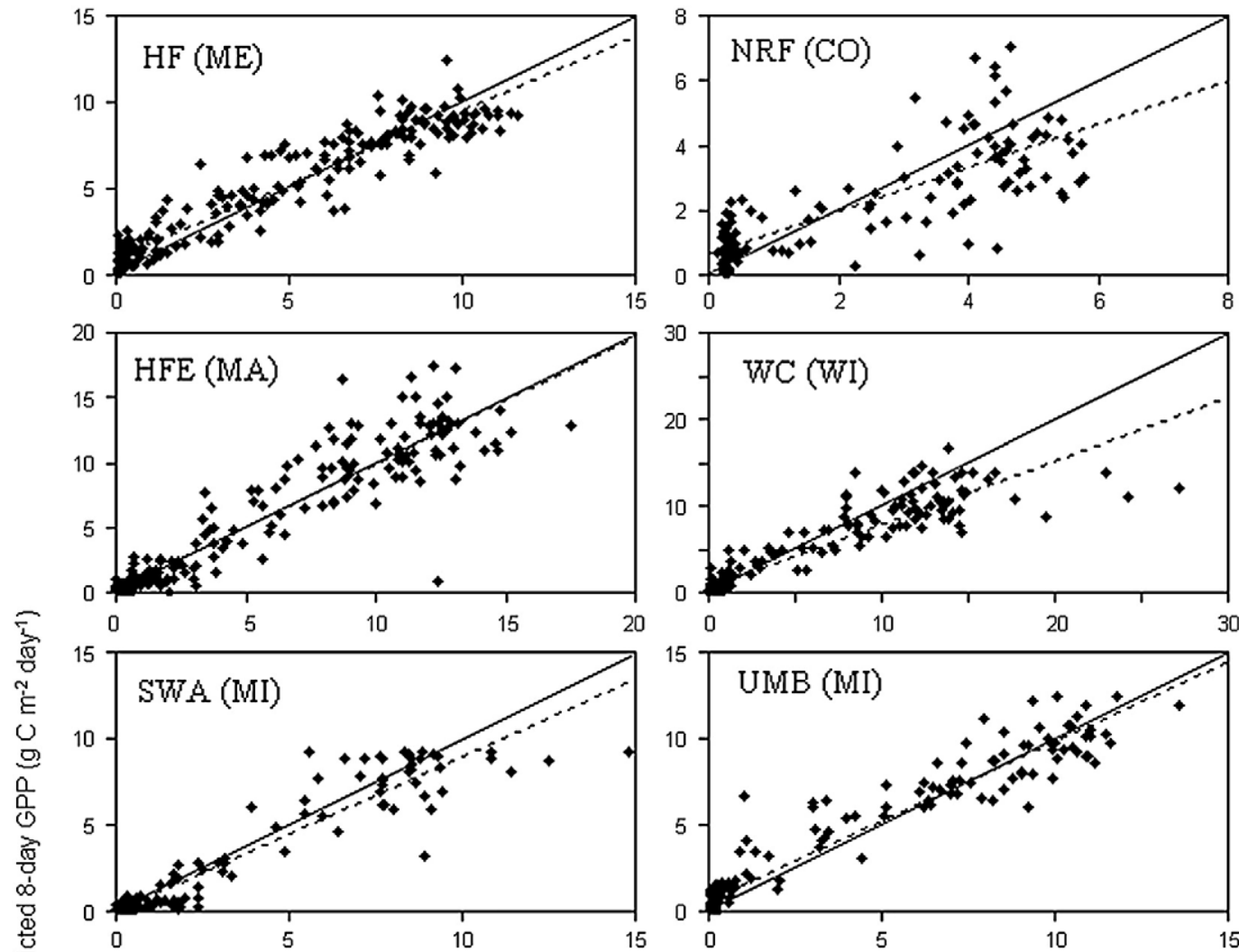

Rule 2: if $\mathrm{LST}_{\text {day }}<=3.27, \mathrm{EVI}>0.22$, then

$G P P=-0.64+4.8 E V I+0.6 N D W I+0.06 L A I$
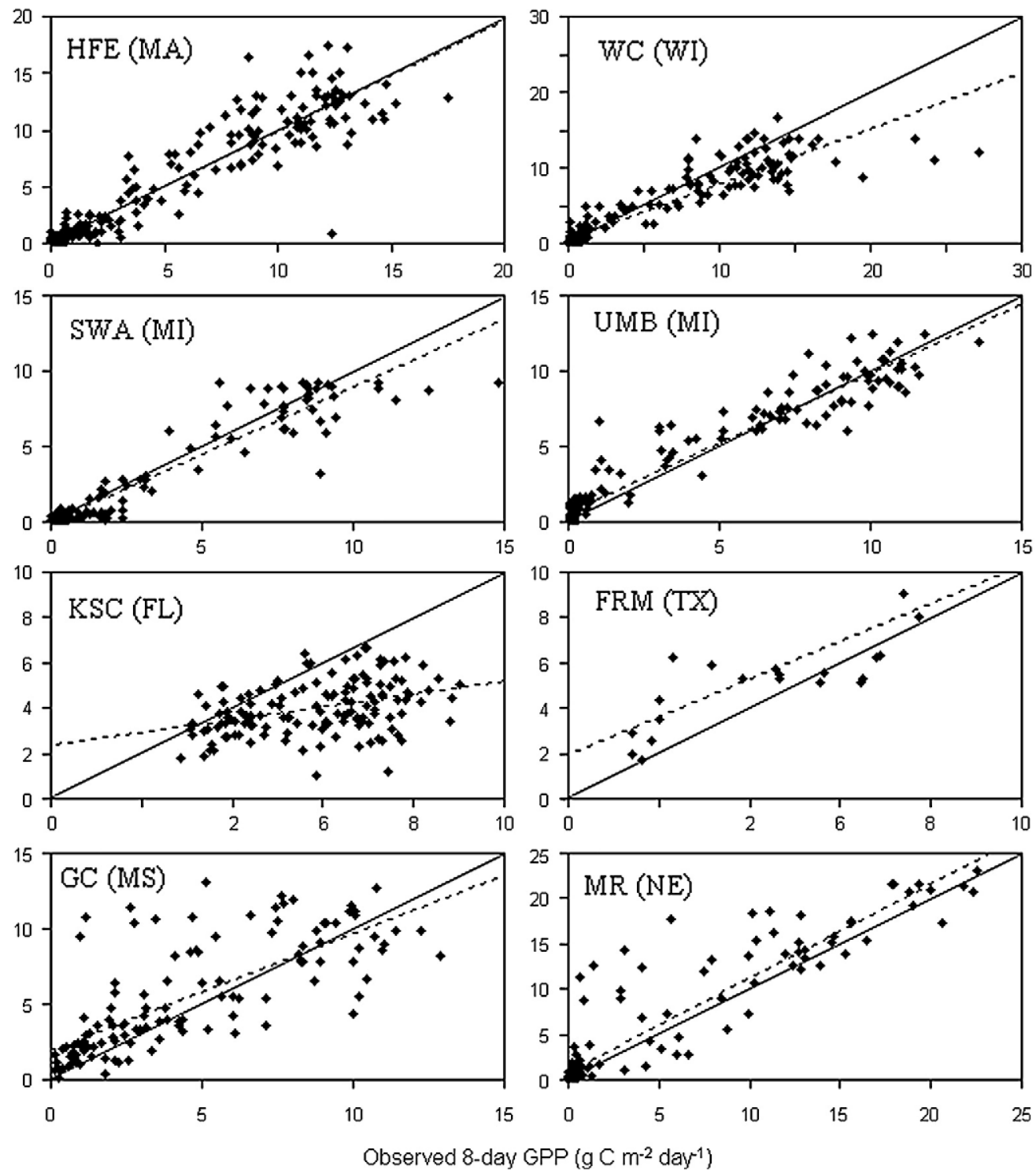

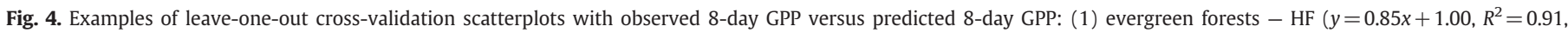

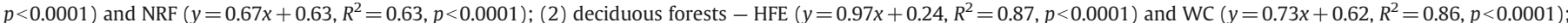

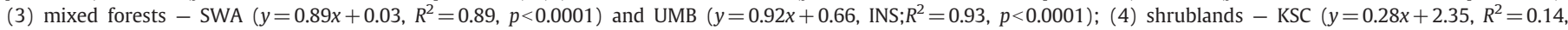

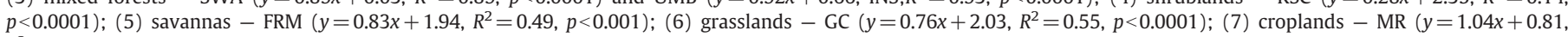

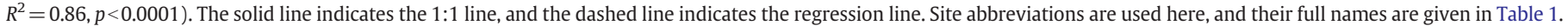


Rule 3: if land cover in \{Evergreen forests, Shrublands, Savannas, Grasslands, Croplands\}, EVI $<=0.22$, $\mathrm{LAI}<=2.64$, then

$G P P=0.15+1.4 E V I+0.01 L S T_{\text {day }}$

Rule 4: if land cover in \{Deciduous forests, Mixed forests, Savannas, Croplands\}, $\mathrm{LST}_{\text {day }}>3.26, \mathrm{EVI}<=0.37, \mathrm{LAI}<=1.78$, then

$G P P=-1.10+0.75 L A I+4.6 E V I$

...

Rule 22: if $\mathrm{NDWI}<=-0.28, \mathrm{LST}_{\mathrm{day}}>17.65, \mathrm{EVI}>0.58$, then

$G P P=10.49+1.9 E V I+0.02 L S T_{\text {day }}-0.7 N D W I$

Rule 23: if land cover $=$ Croplands, $\mathrm{LST}_{\text {day }}>29.92, \mathrm{EVI}>0.37$, then

$G P P=-24.85+5.47 L A I+58.9 E V I+0.124 L S T_{\text {day }}-0.5 N D W I$

where LST $_{\text {day }}$ is the daytime LST. As mentioned earlier, the rules of the model could overlap with one another. For instance, rule 1 overlapped with rule 4 as land cover could be deciduous forests in both cases; rules 22 and 23 also overlapped with each other as EVI could be greater than 0.58 in both cases.

\subsubsection{Model evaluation}

The analysis of model residuals indicated that the residuals were not randomly distributed. Low GPP values were generally associated with low prediction errors, whereas high GPP values were associated with high prediction errors. The uncertainties of carbon flux measurements are directly proportional to the magnitudes of the fluxes (Richardson et al., 2008). The residuals also exhibited a systematic component. For example, large GPP tended to have consistently negative residuals. The residuals also had a random component that arose partially from errors/ uncertainties in the measured fluxes as well as MODIS data. Random errors in AmeriFlux GPP data are significant (Hagen et al., 2006) and these errors may ultimately limit the agreement between observed and predicted GPP values. In addition, the explanatory variables included in the model could not completely explain the variance of GPP. For example, the independent variables used in the model could not account for nitrogen availability, and may affect the accuracy of the model.

We compared our GPP estimates with observed GPP for each AmeriFlux site over the period 2005-2006 (Fig. 2). Our estimates captured most features of observed GPP including seasonality and year-to-year variations over the period 2005-2006. GPP was underand over-predicted for some sites. The model could not capture exceptionally high GPP values for some sites, such as Audubon Research Ranch (AZ), Santa Rita Mesquite (AZ), and Fort Peck (MT). We averaged observed and predicted 8-day GPP for each site, and plotted mean predicted GPP against observed GPP (Fig. 3). The model estimated GPP fairly well at the site level $\left(y=0.95 x+0.21, R^{2}=0.84\right.$, $p<0.0001$; RMSE $=0.77 \mathrm{~g} \mathrm{C} \mathrm{m}^{-2} \mathrm{day}^{-1}$ ). Overall, the model slightly under- and overestimated GPP for values greater or lower than $\sim 4 \mathrm{~g} \mathrm{C} \mathrm{m}^{-2}$ day $^{-1}$, respectively. The model performance also varied with site. Large underestimation occurred at some sites such as the North Carolina Loblolly Pine (NCP, NC), Freeman Ranch Mesquite Juniper (FRM, TX), and Walnut Gulch Kendall Grasslands (WGK, AZ), whereas large overestimation occurred at some sites such as Lost Creek (LC, WI) and Mead Rainfed (MR, NE). The model predicted GPP remarkably well at the biome level $\left(y=0.99 x-0.13, R^{2}=0.91\right.$, $p<0.00001$; RMSE $=0.42 \mathrm{~g} \mathrm{C} \mathrm{m}^{-2}$ day $^{-1}$ ). The model slightly overestimated GPP for deciduous forests and croplands and slightly underestimated GPP for all other biomes.

The disagreement between predicted and observed GPP values is likely due to the following reasons. First, the MODIS and tower footprints do not match with each other and the vegetation structure at the flux tower could be significantly different from that within the MODIS footprint (Xiao et al., 2008). For example, the Tonzi Ranch site (CA) is dominated by deciduous blue oaks (Quercus douglasii) and the understory and open grassland are mainly cool-season $C_{3}$ annual species (Ma et al., 2007). The MODIS footprint consists of a larger fraction of grassland than the tower footprint. Blue oaks and grasses have distinct phenologies (Ma et al., 2007) and therefore had differential contributions to the carbon fluxes integrated over the MODIS footprint over time (Xiao et al., 2008). Second, MODIS data is less sensitive to changes in understory vegetation and damage to canopies that do not increase canopy gaps, leading to overestimation of carbon assimilation rates. Third, the independent variables included in the model could not account for other factors such as nitrogen availability (Clark et al., 1999, 2004) and stand age (Ryan et al., 2004), all of which may influence GPP. Finally, we estimated GPP for each 8-day interval, and therefore our estimates may not capture the variability of GPP within that period. The 8- or 16-day LST and EVI values do not always represent average environmental conditions and average fluxes over the 8- or 16-day period (Xiao et al., 2008), and the exclusion of days with high and low values could lead to underestimation and overestimation of GPP values, respectively. In addition, during drought or days with high vapor pressure deficits, the midday GPP may not be representative because of the skewed diurnal variation in GPP (Anthoni et al., 2000).

\subsubsection{Model validation}

We validated our model in both temporal and spatial domains. We first validated the model in the temporal domain using the test set over the period 2005-2006 (Fig. 1a). Our model estimated GPP fairly well $\left(R^{2}=0.74, p<0.0001 ; \operatorname{RMSE}=1.99 \mathrm{~g} \mathrm{C} \mathrm{m}^{-2}\right.$ day $\left.^{-1}\right)$, although it slightly under- and overestimated GPP values greater and less than $3 \mathrm{~g} \mathrm{C} \mathrm{m}^{-2}$ day $^{-1}$, respectively. By contrast, the MODIS GPP product estimated GPP for the AmeriFlux sites with a RMSE of $2.43 \mathrm{~g} \mathrm{C} \mathrm{m}^{-2} \mathrm{day}^{-1}$ $\left(y=0.50 x+1.01, R^{2}=0.58, p<0.0001\right.$; Fig. $\left.1 \mathrm{~b}\right)$. The $R^{2}$ and RMSE of our model were $28 \%$ higher and $18 \%$ lower than those of the MODIS GPP product, respectively.

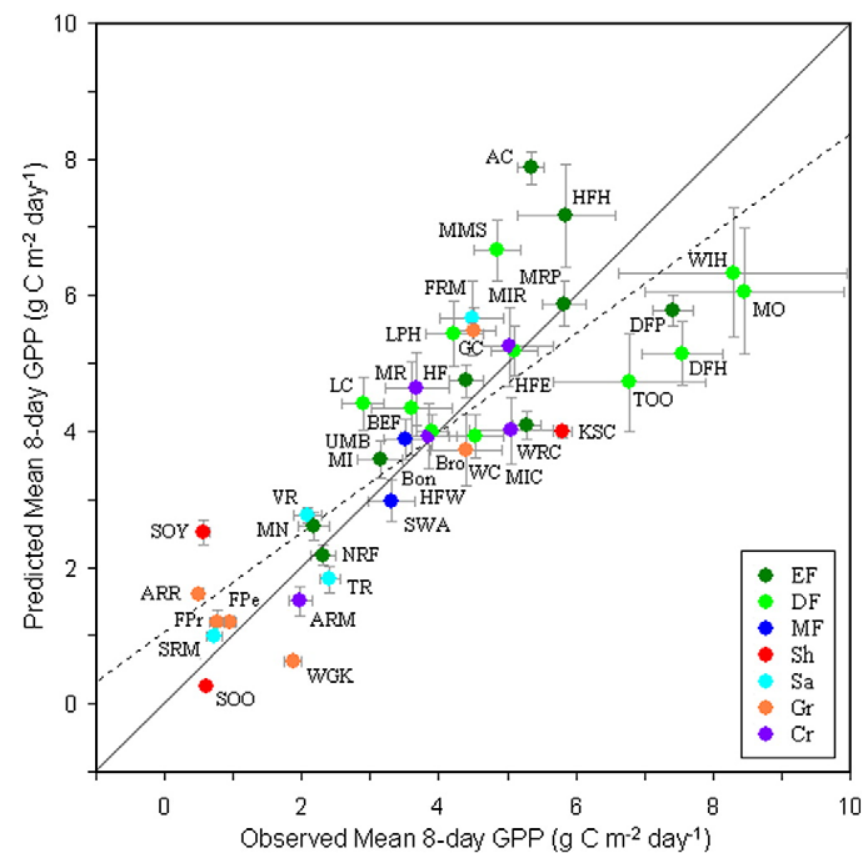

Fig. 5. Leave-one-out cross-validation scatterplot of observed mean 8-day GPP versus predicted mean 8-day GPP across the AmeriFlux sites. Error bars are standard errors of the observed and predicted 8-day GPP. The solid line indicates the 1:1 line, and the dashed line indicates the regression line $\left(y=0.73 * x+1.07, R^{2}=0.69, ; p<0.0001\right)$. Site abbreviations are used here, and their full names are given in Table 1 . 
We then validated the model in the spatial domain using leaveone-out cross-validation. The cross-validation also showed that our model estimated GPP fairly well (Fig. 4). The model performance varied with site and biome type. Our model had a higher performance for forest ecosystems and croplands than shrublands, savannas, and grasslands. We averaged observed and predicted 8-day GPP for each site, and then plotted mean predicted GPP against observed GPP (Fig. 5). The cross-validation showed that our model estimated GPP fairly well at the site level $\left(y=0.73 x+1.07, R^{2}=0.69, p<0.0001\right.$; RMSE $=1.19 \mathrm{~g} \mathrm{C} \mathrm{m}^{-2} \mathrm{day}^{-1}$ ) although the slope and $R^{2}$ were lower and the RMSE was higher than those of the validation in the temporal domain, respectively. The cross-validation also showed that our model estimated GPP remarkably well at the biome level $(y=0.86 x+$ $0.48, R^{2}=0.91, p<0.0001 ; \operatorname{RMSE}=0.33 \mathrm{~g} \mathrm{C} \mathrm{m}^{-2}$ day $^{-1}$ ).

The validation of the model in both temporal and spatial domains showed that the performance of our model is encouraging, given the diversity in ecosystem types, age structures, fire and insect disturbances, and management practices. Our approach extensively used eddy covariance flux tower data involving typical U.S. ecosystem and climate types. Our study demonstrated that our empirical approach has great potential for upscaling flux tower GPP data to continental scales across a variety of biomes.

\subsection{Gross primary production}

\subsubsection{Seasonal patterns}

Our 8-day GPP estimates were highly constrained by eddy flux data, and provided a spatially and temporally continuous measure of GPP with high spatial and temporal resolutions for the conterminous U.S., which made it possible to examine the patterns, magnitude, and interannual variability of GPP across the U.S. Our estimates showed that GPP exhibited large spatial variability and strong seasonal fluctuations (Fig. 6). The seasonal patterns of GPP and its spatial variability reflected the controlling effects of climate conditions. In the spring months, the Southeast and the Gulf Coast significantly assimilated carbon with GPP values reaching $\sim 100-250 \mathrm{~g} \mathrm{C} \mathrm{m}^{-2} \mathrm{mo}^{-1}$ as the growing season started in early to midspring in these regions. The Pacific Coast is dominated by evergreen forests, and these ecosystems also assimilated carbon due to mild temperatures and moist conditions during the spring (Anthoni et al., 2002). The Mediterranean regions in California also assimilated carbon in the spring because of a surplus of precipitation and relatively warm temperatures (Ma et al., 2007; Xu \& Baldocchi, 2004). By contrast, the Upper Great Lakes region and the northern Great Plains are dominated by croplands with most crops planted between April and June (Shroyer et al., 1996), whereas the New England region and the northern portion of the

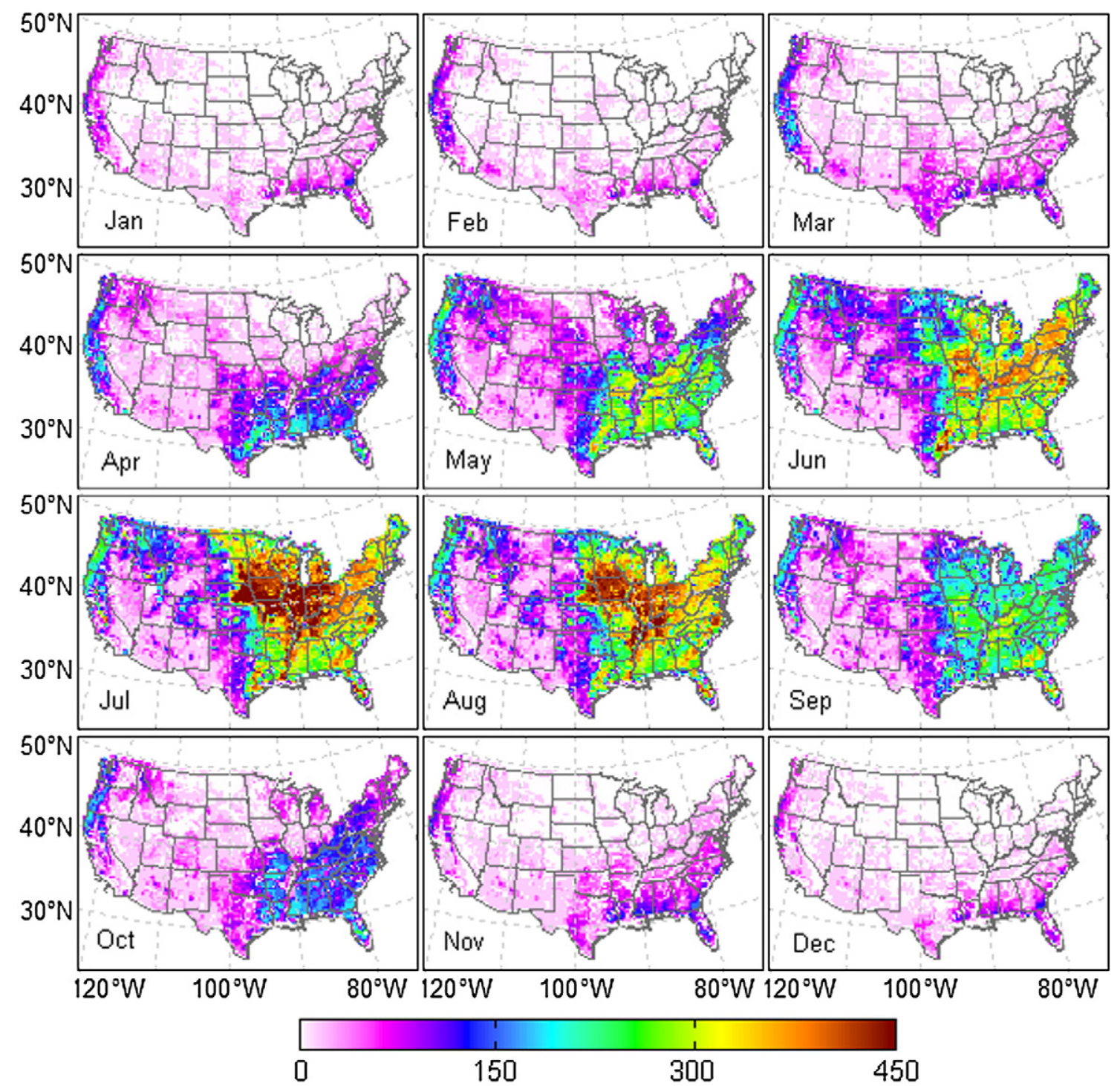

Fig. 6. Monthly GPP $\left(\mathrm{g} \mathrm{C} \mathrm{m}^{-2} \mathrm{mo}^{-} 1\right)$ for the conterminous U.S. from January through December in 2005. 
Upper Great Lakes region are dominated by temperate-boreal transitional forests. The relatively late greenup in these regions led to low GPP.

In the summer months, the eastern U.S., the Coastal Pacific Northwest, and some regions in California exhibited high GPP values $(\sim 250$ $450 \mathrm{~g} \mathrm{C} \mathrm{m}^{-2} \mathrm{mo}^{-1}$ ) owing to favorable temperature and soil moisture conditions, while the vast majority of western landscapes, including the Great Basin, the Colorado Plateau, and the western Great Plains exhibited much lower GPP values due to spare vegetation and precipitation deficits.

In the fall months (September-November), the GPP values of the Southeast and the Gulf Coast substantially decreased relative to those in the summer because vegetation began to senesce and days became shorter in these regions. The spatial patterns and magnitude of GPP were similar to those of the spring. The Upper Great Lakes region and the Great Plains had very low GPP values due to the harvesting of crops.

In the winter months (December-February), the majority of the U.S. had little or no photosynthesis as the canopies of most ecosystems were dormant. Some regions in the Pacific Coast, California, the Gulf Coast, and the Southeast slightly assimilated carbon because of the dominance of evergreen forests and mild temperatures (Anthoni et al., 2002; Clark et al., 1999; McGarvey et al., 2004; Waring \& Franklin, 1979). For example, Douglas-fir, a major species in the Pacific Northwest and California, is known to be highly plastic and able to photosynthesize in winter when temperatures are above the freezing point (Xiao et al., 2008).

Fig. 7 showed the trajectories of the spatially averaged and integrated 8-day GPP for each biome from February 2000 to December 2006. Deciduous forests and croplands had the largest intra-annual

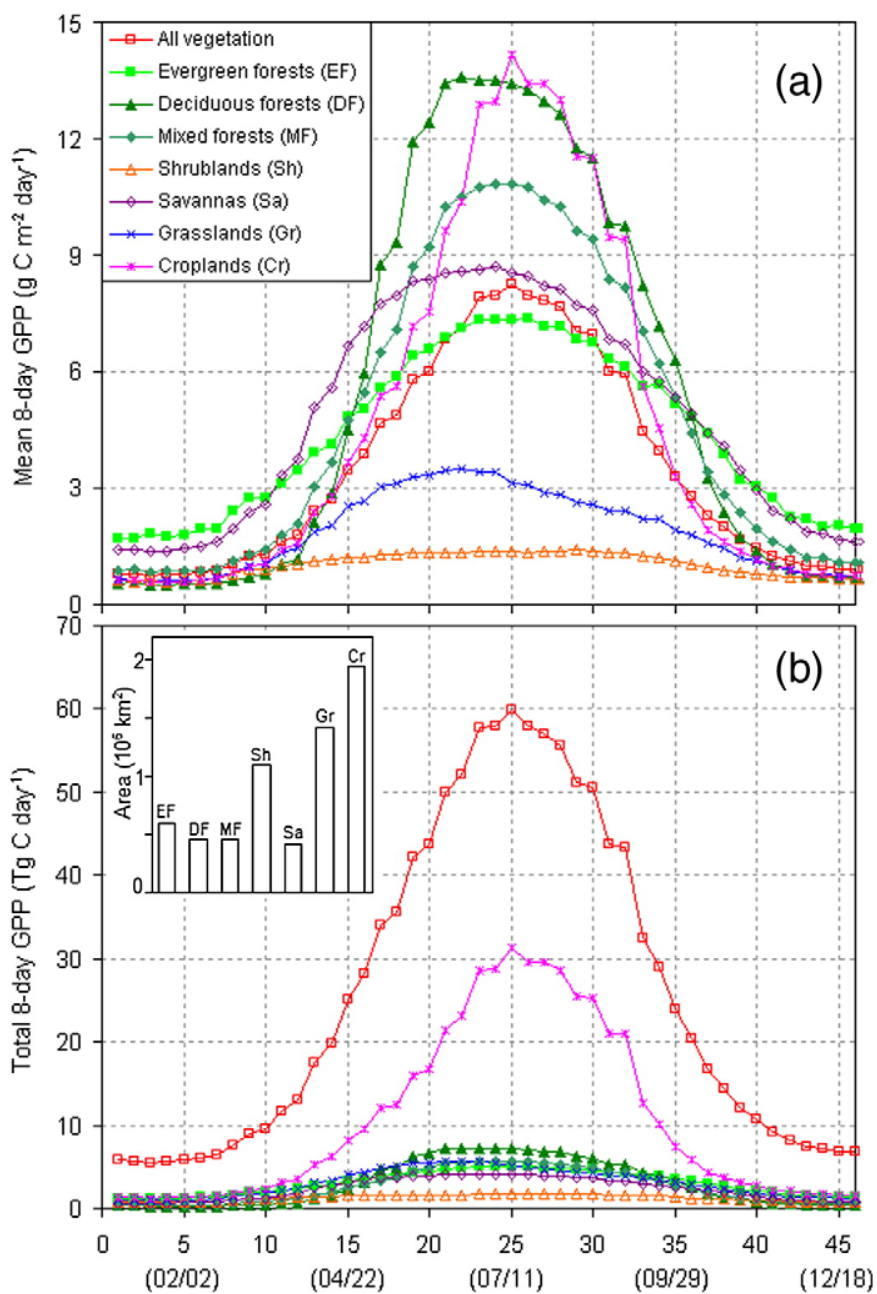

Fig. 7. Spatially averaged and integrated 8-day GPP for each biome across the conterminous U.S. over the period 2001-2006. (a) Spatially averaged 8-day GPP ( $\mathrm{g} \mathrm{C} \mathrm{m}^{-2}$ day $\left.^{-1}\right)$. (b) Spatially integrated 8-day GPP $\left(\mathrm{Tg} C\right.$ day $^{-1}$ ). variability in spatial averaged GPP, followed by mixed forests; evergreen forests and savannas had intermediate intra-annual variability; grasslands and shrublands had the least variability (Fig. 7a). The temporal variability of spatially integrated GPP (or spatial total) also showed clear dependence on biome (Fig. 7b). Collectively, the terrestrial ecosystems substantially assimilated carbon and had a peak spatial total of 50$55 \mathrm{Tg} \mathrm{C}_{\text {day }}{ }^{-1}$. Taken separately, croplands had the highest intraannual variability in spatially integrated GPP, with a peak spatial total of 25-30 Tg C day ${ }^{-1}$, followed by deciduous forests; evergreen forests, mixed forests, savannas, and grasslands had intermediate intra-annual variability in spatially integrated GPP; shrublands had the least variability. Both spatially averaged and integrated GPP showed interannual variability for each biome.

\subsubsection{Annual fluxes}

We calculated annual GPP for each year over the period 2001-2006 from our 8-day GPP estimates, and then calculated the average annual GPP over the 6-year period (Fig. 8). Annual GPP varied considerably over space, and exhibited a large spatial gradient from the east to the west. The Gulf Coast, the Southeast, the coastal Pacific Northwest, and a part of the Pacific Southwest had high annual GPP $\left(\sim 1500-2000 \mathrm{~g} \mathrm{C} \mathrm{m}^{-2} \mathrm{yr}^{-1}\right)$; the Midwest and the Northeast had intermediate values ( 1200$1500 \mathrm{~g} \mathrm{C} \mathrm{m}^{-2} \mathrm{yr}^{-1}$ ), and the majority of the western half of the country including the Southwest, the western Great Plains, and the Rocky Mountain region had GPP values generally lower than $500 \mathrm{~g} \mathrm{C} \mathrm{m}^{-2} \mathrm{yr}^{-1}$.

We estimated a total gross carbon uptake of $7.06 \mathrm{Pg} \mathrm{C} \mathrm{yr}^{-1}$ for the conterminous U.S. over the period 2001-2006. A quantitative breakdown of the 6-yr average annual GPP map by regions (Table 2) showed that the North Central and South Central regions had the highest GPP, followed by the Southeast, the Rocky Mountain region, and the Northeast; the Pacific Northwest and the Pacific Southwest had the lowest GPP. The spatially averaged annual GPP of the U.S. was $\sim 1100 \mathrm{~g} \mathrm{C} \mathrm{m}^{-2} \mathrm{yr}^{-1}$ (Table 2). Regionally, the Southeast had the highest spatially averaged annual GPP, followed by the Northeast and the South Central regions; the North Central region, the Pacific Northwest, and the Pacific Southwest had intermediate values; the Rocky Mountain region had the lowest spatially averaged annual GPP.

A quantitative breakdown of the 6-yr average annual GPP by biomes (Table 3 ) showed spatially integrated annual GPP varied with biome. Croplands had the highest spatially integrated annual GPP; shrublands had lowest annual GPP; other biomes including evergreen forests, deciduous forests, mixed forests, savannas, and grasslands had intermediate annual GPP. Spatially averaged annual GPP also varied with biome (Table 3). Deciduous forests had the highest spatially averaged annual GPP, followed by evergreen forests, mixed forests, croplands, and savannas; grasslands had intermediate values; shrublands had the lowest values.

We compared our annual GPP estimate with annual GPP estimate from the MODIS GPP product (MOD17A3; Running et al., 2004) for 2005 (Fig. 9). Both estimates showed a large spatial gradient from the east to the west: the Southeast had the highest annual GPP; the Midwest had intermediate annual GPP, while the Rocky Mountain region had the lowest GPP. Both estimates showed that annual GPP is $\sim 300 \mathrm{~g} \mathrm{C} \mathrm{m}^{-2} \mathrm{yr}^{-1}$ in the Rocky Mountain region. Annual GPP is also very similar in the New England region and the Upper Peninsula of Michigan. However, large discrepancies were observed between our estimate and the MODIS GPP product. Our estimate exhibited larger spatial variability than the estimate from the MODIS GPP product. Moreover, compared to our estimate, the MODIS GPP product substantially underestimated GPP in some regions, particularly the Midwest and the coastal Pacific Northwest where ecosystems are highly productive. For example, our annual GPP for the croplands in the Midwest is $\sim 1200-1500 \mathrm{~g} \mathrm{C} \mathrm{m}^{-2} \mathrm{yr}^{-1}$, while the MODIS annual GPP is only $\sim 700 \mathrm{~g} \mathrm{C} \mathrm{m}^{-2} \mathrm{yr}^{-1}$. In many areas in the Southeast, our annual GPP estimate is $\sim 1500-2000 \mathrm{~g} \mathrm{C} \mathrm{m}^{-2} \mathrm{yr}^{-1}$, while the MODIS annual GPP is only $\sim 1000-1500 \mathrm{~g} \mathrm{C} \mathrm{m}^{-2} \mathrm{yr}^{-1}$. 


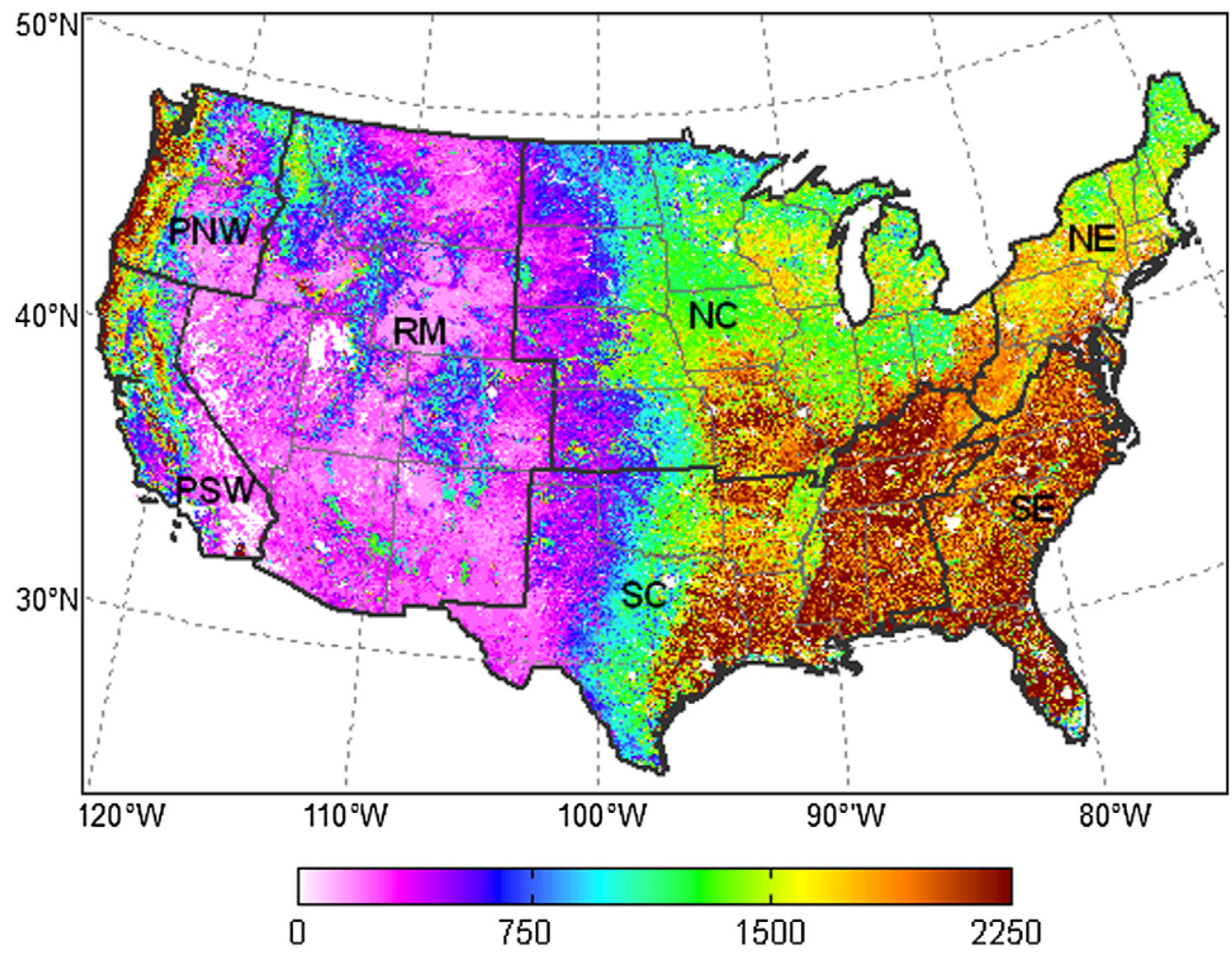

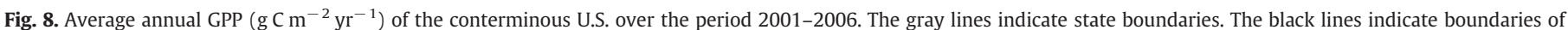
geographical regions: Northeast (NE), Southeast (SE), North Central (NC), South Central (SC), Rocky Mountain (RM), Pacific Northwest (PNW), and Pacific Southwest (PSW).

The large discrepancies in annual GPP between our estimate and the MODIS GPP product can be attributed to the following reasons. First, the MODIS GPP product was developed using an algorithm optimized for global applications and meteorological fields with coarse resolution ( 1 by $1.25^{\circ}$ ) and large uncertainties (Zhao et al., 2006), and thereby likely contributed to the smaller spatial variability of MODIS GPP and affected the accuracy of the MODIS GPP estimates. Second, the maximum light use efficiency $\left(\varepsilon_{\max }\right)$ is an essential parameter of the LUE model used to develop the MODIS GPP product. The $\varepsilon_{\max }$ is only $0.68 \mathrm{~g} \mathrm{C} \mathrm{MJ}^{-1}$ for croplands in the MOD17 algorithm (Heinsch et al., 2003), which is likely too low for croplands and results in substantial underestimation of cropland GPP. Zhang et al. (2008) showed that MODIS annual GPP for an irrigated cropland in China was only about $20-30 \%$ of annual GPP derived from eddy covariance flux measurements, and attributed the substantial underestimation of cropland GPP to the underestimation of $\varepsilon_{\max }$ in the MOD17 algorithm. Third, our estimate was highly constrained eddy flux data, while some geographical regions and biomes are underrepresented by the AmeriFlux network, which could affect the accuracy of our estimates. For example, we merged savannas (tree cover 10-30\%) and woody savannas (tree cover 30-60\%) together in the development of the model because no sites representing typical savannas with tree cover below $30 \%$ were available, which could lead to significant overestimation of GPP for areas that were classified as savannas (tree cover 10-30\%).

Global annual GPP has been estimated to be $120 \mathrm{Pg} \mathrm{C} \mathrm{yr}^{-1}$ using ${ }^{18} \mathrm{O}$ measurements of atmospheric $\mathrm{CO}_{2}$ (Ciais et al., 1997) and $110 \mathrm{Pg} \mathrm{C} \mathrm{yr}^{-1}$ from 2001 to 2003 using the MODIS GPP product (Zhao et al., 2005). Our estimates suggested that the terrestrial ecosystems in the conterminous U.S. accounted for 5.9-6.5\% of the global annual GPP, while its land area accounts for $\sim 5.4 \%$ of the global land area. Our estimate of U.S. annual GPP was higher than other estimates. For example, the average annual GPP over the period 2001-2006 derived from MODIS GPP product (Running et al., 2004) was $\sim 6.2 \mathrm{Pg} \mathrm{C} \mathrm{yr}^{-1}$. Our estimate was about $14 \%$ higher than the MODIS GPP estimate. Potter et al. (2007) estimated annual NPP between 2.67 and $2.79 \mathrm{Pg} \mathrm{C} \mathrm{yr}^{-1}$ over the period 20012004 using MODIS data and the NASA-CASA model. Our estimate was also higher than that estimated by Potter et al. (2007) assuming that NPP is about half of GPP (Lloyd \& Farquhar, 1996; Waring et al., 1998).

Our predictive model has advantages over empirical or processbased ecosystem models. Most ecosystem models are dependent on site-level parameterizations that are used as default parameters for a much broader spectrum of vegetation types and conditions, which may limit the accuracy of model simulations over large areas (e.g., Prince \& Goward, 1995; Running et al., 2004; Xiao et al., 2009). By contrast, our model was highly constrained by eddy flux data from a number of towers encompassing a range of ecosystem and climate types, and may lead to model parameters that are more representative of the full spectrum of vegetation and climate types and thereby more accurate estimates of carbon fluxes at regional scales. Moreover, our model consisted of rule-based, multivariate linear regression models, and is easier to understand and implement. Our model could substantially

Table 2

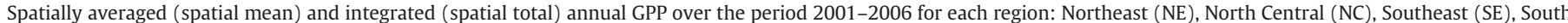
Central (SC), Rocky Mountain (RM), Pacific Northwest (PNW), and Pacific Southwest (PSW).

\begin{tabular}{|c|c|c|c|c|c|c|c|c|}
\hline GPP & NE & $\mathrm{NC}$ & SE & SC & RM & PNW & PSW & US \\
\hline Spatial mean $\left(\mathrm{g} \mathrm{C} \mathrm{m}^{-2} \mathrm{yr}^{-1}\right)$ & 1604.20 & 1212.55 & 2033.91 & 1457.97 & 438.20 & 1007.35 & 927.77 & 1103.92 \\
\hline Spatial total $\left({\left.\mathrm{Pg} \mathrm{C} \mathrm{yr}^{-1}\right)}^{-1}\right.$ & 0.67 & 2.00 & 1.00 & 1.93 & 0.81 & 0.36 & 0.29 & 7.06 \\
\hline
\end{tabular}


Table 3

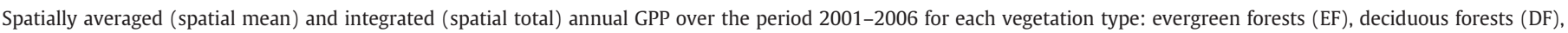
mixed forests (MF), shrublands (Sh), savannas (Sa), grasslands ( $\mathrm{Gr}$ ), and croplands ( $\mathrm{Cr}$ ).

\begin{tabular}{|c|c|c|c|c|c|c|c|c|}
\hline GPP & $\mathrm{EF}$ & $\mathrm{DF}$ & MF & Sh & $\mathrm{Sa}$ & $\mathrm{Gr}$ & $\mathrm{Cr}$ & All \\
\hline Spatial mean $\left(\mathrm{gC} \mathrm{m}^{-2} \mathrm{yr}^{-1}\right)$ & 1431.26 & 1774.74 & 1447.31 & 303.78 & 1500.96 & 589.24 & 1500.38 & 1103.92 \\
\hline Spatial total $\left(\mathrm{Pg} \mathrm{C} \mathrm{yr}^{-1}\right)$ & 0.85 & 0.83 & 0.67 & 0.33 & 0.63 & 0.83 & 2.92 & 7.06 \\
\hline
\end{tabular}

reduce computational complexity compared to many ecosystem models. On the other hand, however, our model also has disadvantages over ecosystem models. Our model is an empirical approach, and does not involve ecosystem processes such as photosynthesis and nitrogen cycling. Moreover, our model did not explicitly consider some factors influencing GPP such as nitrogen availability, stand age, and disturbance history that may be explicitly simulated in process-based ecosystem models (e.g., Aber et al., 1997). All these model differences contributed to the discrepancies in annual GPP estimates between our empirical approach and ecosystem models.

(a)

(b)

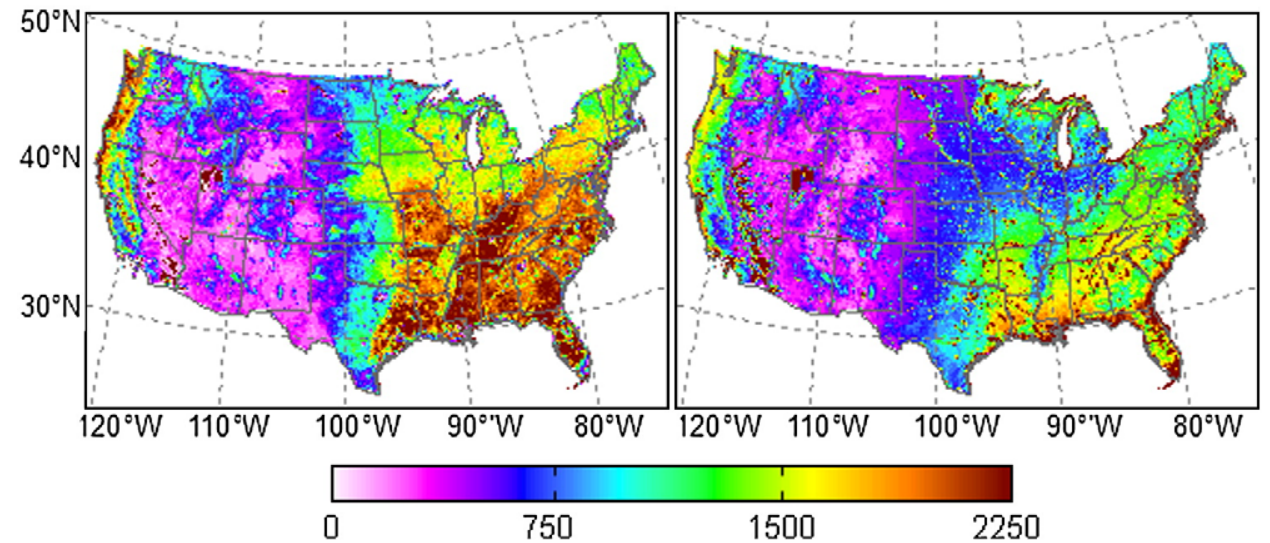

Fig. 9. Annual GPP $\left(\mathrm{g} \mathrm{C} \mathrm{m}^{-2} \mathrm{yr}^{-1}\right)$ for the conterminous U.S. for 2005. (a) Our estimate. (b) The MODIS GPP product (MOD17A3; Running et al., 2004).
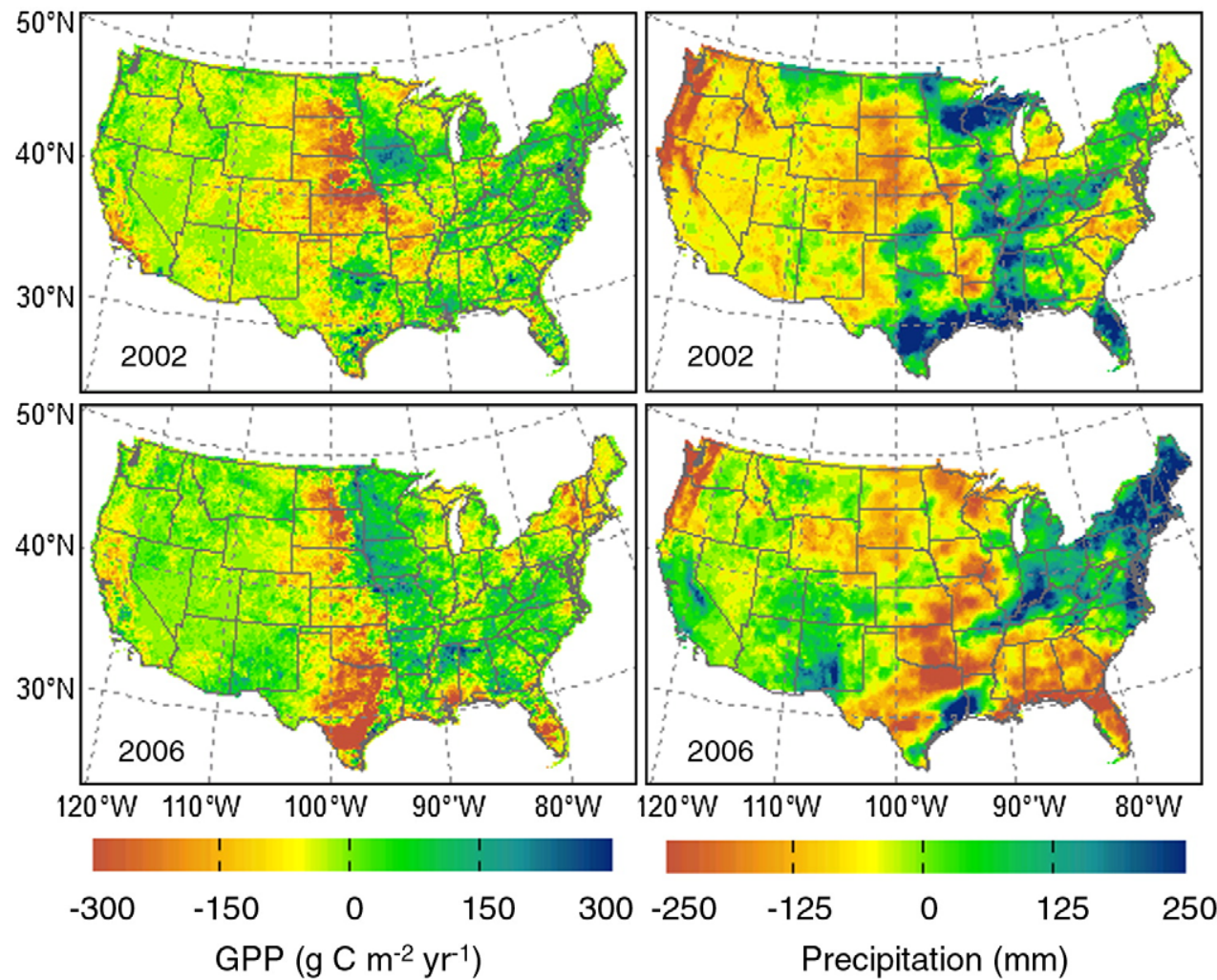

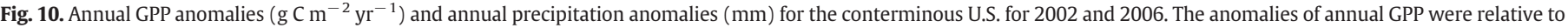

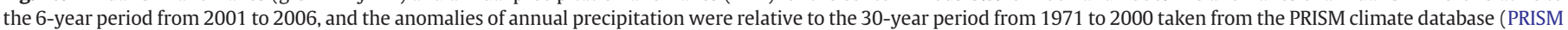
Climate Group, 2004). 


\subsubsection{Interannual variability}

The U.S. annual GPP varied between 6.91 and $7.33 \mathrm{Pg} \mathrm{C} \mathrm{yr}^{-1}$ over the period 2001-2006. The years 2002, 2004, and 2006 had lower GPP values relative to 2001, 2003, and 2005. Annual GPP exhibited positive and negative anomalies for each year, and the spatial patterns of these anomalies also varied from year to year (Fig. 10). The annual GPP anomalies were likely due to climate variability, disturbances, and management practices. Moderate to severe drought affected over $50 \%$ of the country in both years, including the Southwest, the Great Plains, the Gulf Coast, and the coastal Southeast, particularly Texas and Oklahoma (U.S. Drought Monitor, http://www.drought.unl.edu). The annual precipitation of these two years was 467 and $458 \mathrm{~mm}$ for the U.S., respectively - lower than the 30 -year mean annual precipitation ( $480 \mathrm{~mm}$ ) taken over the PRISM climate database. Our GPP anomaly maps showed large negative GPP anomalies in many of the droughtaffected regions. Notably, large negative GPP anomalies occurred in the Great Plains in 2002 and 2006. Our results further demonstrated severe drought could substantially affect ecosystem carbon fluxes (Xiao et al., 2009).

At landscape to regional scales, annual GPP also exhibited large anomalies. For example, our results showed that the Biscuit fire in Oregon led to large negative GPP anomalies in the burned area (Fig. 11). The 2002 Biscuit Fire was among the largest forest fires in modern U.S. history, encompassing $>2000 \mathrm{~km}^{2}$ primarily within the Rogue-Siskiyou National Forest (RSNF) in southwest Oregon (Campbell et al., 2007; Thompson et al., 2007). Large fires such as the Biscuit Fire damaged both overstory and/ or understory vegetation, leading to a reduction in GPP and large negative GPP anomalies in the region in 2003, which may result in net carbon release into the atmosphere. Numerous wildfires occurred over the western half of the country due to dry weather and high winds, burning $1.5-4.0 \times 10^{4} \mathrm{~km}^{2}$ of forests from 2000 to 2006 (U.S. Fire Administration, http://www.usfa.dhs.gov). The drought along with wildfires likely led to the negative GPP anomalies in the western half of the U.S.

Our results also showed hurricanes could reduce GPP and lead to large negative GPP anomalies (Fig. 12). For example, Hurricane Katrina occurred in late August 2005 affected over $2 \times 10^{4} \mathrm{~km}^{2}$ of forest across Mississippi, Louisiana and Alabama, with damage ranging from downed trees, snapped trunks and broken limbs to stripped leaves (USDA Forest Service, http://www.srs.fs.usda.gov). Forest inventories indicated that the potential timber losses from Hurricane Katrina amounted to roughly $1.2 \times 10^{8} \mathrm{~m}^{3}$ (USDA Forest Service, http://www. srs.fs.usda.gov). Our results showed large negative GPP anomalies in 2006 in the Gulf Coast region severely affected by Hurricane Katrina (Fig. 12). The reduction in GPP and increased $R_{\mathrm{e}}$ resulting from increased litter could lead to substantial carbon release into the atmosphere (Chambers et al., 2007).

\section{Conclusions}

We used a regression tree approach and remotely sensed data from MODIS to upscale AmeriFlux GPP data to the continental scale and to produce a GPP dataset with 8-day temporal resolution and $1 \mathrm{~km}$ spatial resolution for the conterminous U.S. over the period 2000-2006. Our results demonstrated that our empirical approach has great potential for upscaling eddy flux GPP data to large areas across multiple biomes. Our GPP estimates provided a spatially and temporally continuous measure of gross primary production for the conterminous U.S. Our estimates also provided an alternative, independent dataset from the MODIS GPP product and simulations with biogeochemical models. Our GPP estimates were highly constrained by flux tower data from towers encompassing a large range of ecosystem and climate types as well as disturbance history. Our approach can be applied to the entire North America, other geographic regions including Europe, Southeast Asia, and South America, or to the global scale, and to produce continuous GPP estimates over continents or the globe. This approach (a)

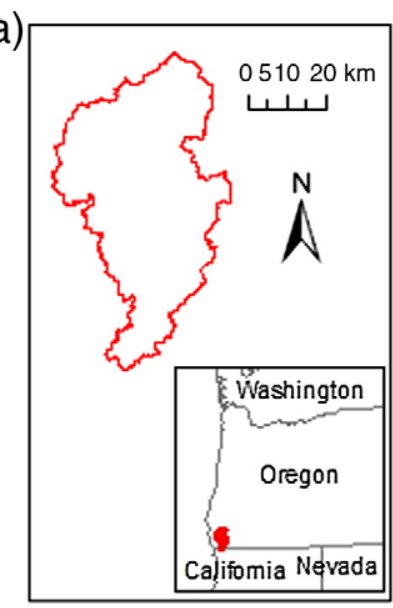

(c)

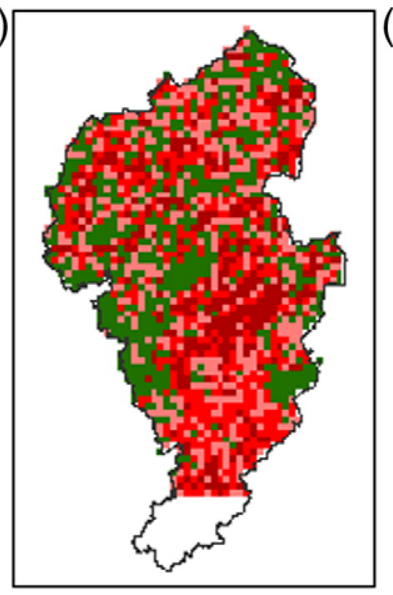

Burn severity

Little or no change

Green \& dead mixed

Dead trees with needles - Dead trees without needles (b)

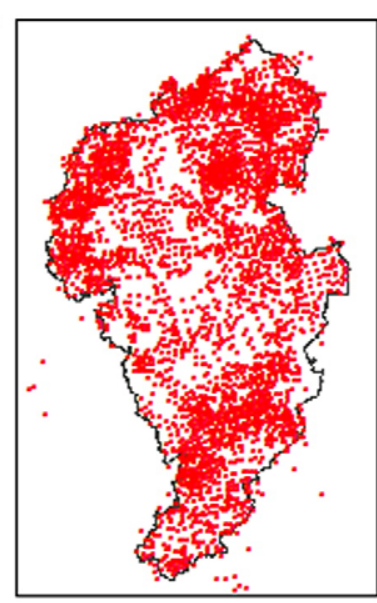

(d)

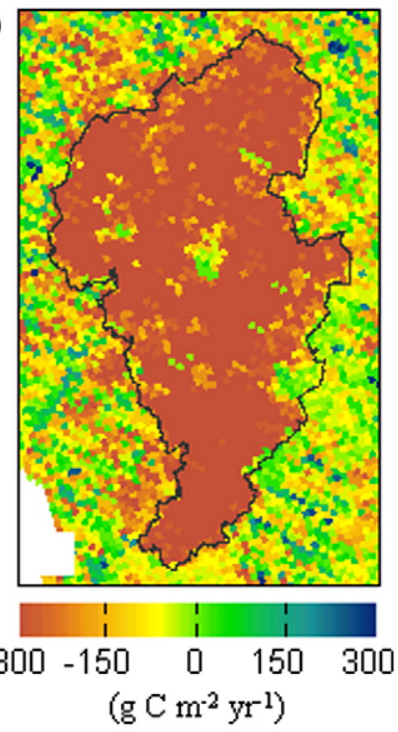

$0 \quad 10 \quad 20 \quad 40 \mathrm{~km}$

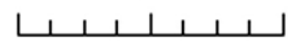

Fig. 11. Impact of the Biscuit Fire $\left(>2000 \mathrm{~km}^{2}\right)$ in Oregon on annual GPP in 2004 (a) Burned area. (b) The dots represent fire detections from Terra MODIS and Aqua MODIS MODIS (USDA Forest Service MODIS Active Fire Mapping Program, http:// activefiremaps.fs.fed.us). (c) Burn severity based on the difference normalized burn ratio (dNBR; Lutes et al., 2004) from Landsat Thematic Mapper (TM) data acquired before and immediately after the fire. (d) Annual GPP anomalies in $2003\left(\mathrm{~g} \mathrm{C} \mathrm{m}^{-2} \mathrm{yr}^{-1}\right)$.

can also be used to upscale other fluxes including evapotranspiration to large areas.

Our GPP estimates exhibited large spatial variability and strong seasonal variations, which reflected the controlling effects of climate conditions and vegetation distributions. We estimated a total gross carbon uptake of $7.06 \mathrm{Pg} \mathrm{C} \mathrm{yr}^{-1}$ for the conterminous U.S. over the period 2001-2006. Annual GPP varied substantially with geographical region and biome type. Our results also showed that the U.S. annual GPP varied between 6.91 and $7.33 \mathrm{PgC} \mathrm{yr}^{-1}$ over the 6-year period. Extreme climate events (e.g., drought) and disturbances (e.g., fires and hurricanes) reduced annual GPP at regional scales and could have a significant impact on the U.S. net ecosystem carbon exchange. The interannual variability of GPP was mainly caused by these extreme climate events (e.g., drought) and disturbances (e.g., fire, hurricane).

\section{Acknowledgements}

This research was partly supported by the National Science Foundation (NSF) Carbon and Water Program (EAR-0630319). We 


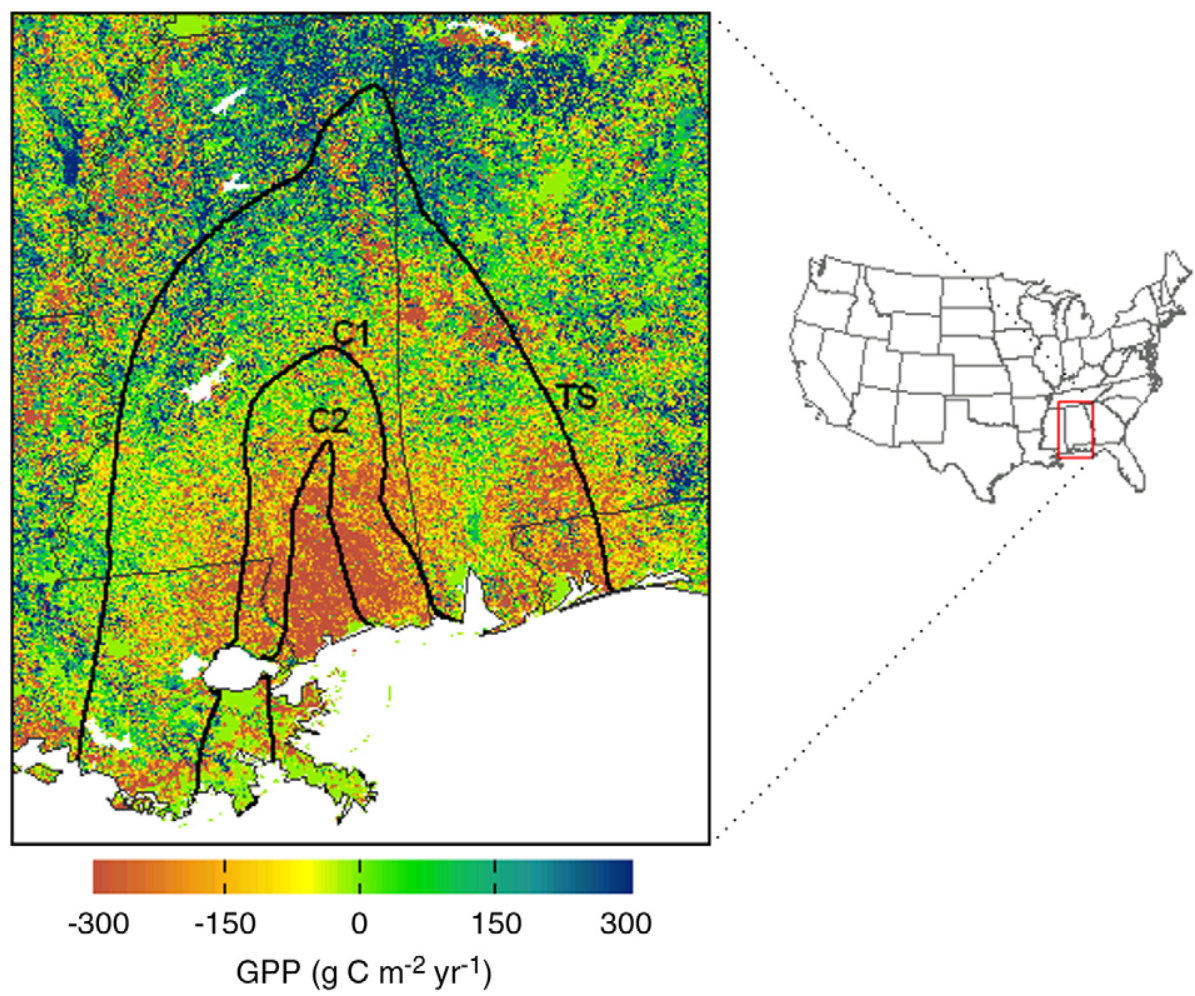

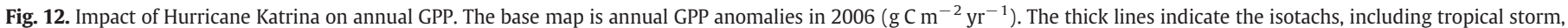
hurricane category 1 , and hurricane category 2 .

thank the principal investigators of the MODIS data products including Drs. A.R. Huete, R.B. Myneni, S.W. Running, E.F. Vermote, and Z. Wan. We also thank D.A. Sims, T.A. Boden, S.K.S. Vannan, M. Zhao, Z. Wan, and L. Delp for helpful discussion. The MODIS data products were obtained from the Oak Ridge National Laboratory (ORNL) Distributed Active Archive Center (DAAC) and the Earth Observing System (EOS) Data Gateway for making these products available. The PRISM climate database was provided by the PRISM Group, Oregon State University (http://www.prismclimate.org).

\section{References}

Aber, J. D., Ollinger, S. V., \& Driscoll, C. T. (1997). Modeling nitrogen staturation in fores ecosystems in response to land use and atmospheric deposition. Ecological Modelling, 101, 61-78.

Anthoni, P. M., Law, B. E., Unsworth, M. H., \& Vong, R. J. (2000). Variation of net radiation over heterogeneous surfaces: measurements and simulation in a junipersagebrush ecosystem. Agricultural and Forest Meteorology, 102, 275-286.

Anthoni, P. M., Unsworth, M. H., Law, B. E., Irvine, J., Baldocchi, D. D., Tuyl, S. V., et al. (2002). Seasonal differences in carbon and water vapor exchange in young and oldgrowth ponderosa pine ecosystems. Agricultural Forest Meteorology, 111, 203-222.

Asrar, G., Fuchs, M., Kanemasu, E. T., \& Hatfield, J. L. (1984). Estimating of absorbed photosynthesis radiation and leaf area index from spectral reflectance in wheat. Agronomy Journal, 76, 300-306.

Baldocchi, D., Falge, E., Gu, L., Olson, R., Hollinger, D., Running, S., et al. (2001). FLUXNET: A new tool to study the temporal and spatial variability of ecosystem-scale carbon dioxide, water vapor, and energy flux densities. Bulletin of the American Meteorological Society, 82, 2415-2434.

Campbell, J., Donato, D., Azuma, D., \& Law, B. (2007). Pyrogenic carbon emission from a large wildfire in Oregon, United States. Journal of Geophysical Research, 112, G04014. doi:10.1029/2007JG000451.

Chambers, J. Q., Fisher, J. I., Zeng, H., Chapman, E. L., Baker, D. B., \& Hurtt, G. C. (2007). Hurricane Katrina's carbon footprint on U.S. Gulf Coast forests. Science, 318, 1107.

Chen, X., Vierling, L., Powell, E., \& DeFelice, T. (2004). Using lidar and effective LAI data to evaluate IKONOS and Landsat 7 ETM + vegetation cover estimates in ponderosa pine forest. Remote Sensing of Environment, 91, 14-26.

Ciais, P., Tans, P. P., Denning, A. S., Francey, R. J., Trolier, M., Meijer, H. A. J., et al. (1997). A thee-dimensional synthesis study of y180 in atmospheric CO2. 1. surface fluxes. Journal of Geophysical Research, D102, 5857-5872.
Clark, K. L., Gholz, H. L., \& Castro, M. S. (2004). Carbon dynamics along a chronosequence of slash pine plantations in N. Florida. Ecological Applications, 4, 1154-1171.

Clark, K. L., Gholz, H. L., Moncrieff, J. B., Cropley, F., \& Loescher, H. W. (1999). Environmental controls over net carbon dioxide from contrasting Florida ecosystems. Ecological Applications, 9, 936-948.

Cook, B. D., Davis, K. J., Wang, W., Desai, A., Berger, B. W., Teclaw, R. M., et al. (2004). Carbon exchange and venting anomalies in an upland deciduous forest in northern Wisconsin, USA. Agricultural Forest Meteorology, 126, 271-295.

Desai, A. R., Bolstad, P. V., Cook, B. D., Davis, J., \& Carey, E. V. (2005). Comparing net ecosystem exchange of carbon dioxide between an old-growth and mature forest in the upper Midwest, USA. Agricultural Forest Meteorology, 128, 33-55.

Desai, A. R., Richardson, A. D., Moffat, A. M., Kattge, J., Hollinger, D. Y., Barr, A., et al. (2008). Cross site evaluation of eddy covariance GPP and RE decomposition techniques. Agricultural and Forest Meteorology, 148, 821-838.

Dore, S., Hymus, G. J., Johnson, D. P., Hinkle, C. R., Valentini, R., \& Drake, B. G. (2003). Cross validation of open-top chamber and eddy covariance measurements of ecosystem $\mathrm{CO}_{2}$ exchange in a Florida scrub-oak ecosystem. Global Change Biology, 9, 84-95.

Falk, M. Wharton, S., Schroeder, M., Ustin, S. \& Paw U, K. T. (2008). Flux partitioning in an old-growth forest: Seasonal and interannual dynamics. Tree Physiology, 28, 509-520.

Fensholt, R., \& Sandholt, I. (2003). Derivation of a shortwave infrared water stress index from MODIS near- and shortwave infrared data in a semiarid environment. Remote Sensing Environment, 87, 111-121.

Friedl, M. A., McIver, D. K., Hodges, J. C. F., Zhang, X. Y., Muchoney, D., Strahler, A. H., et al. (2002). Global land cover mapping from MODIS: Algorithms and early results. Remote Sensing Environment, 83, 287-302.

Gao, B. C. (1996). NDWI - a normalized difference water index for remote sensing of vegetation liquid water from space. Remote Sensing Environment, 58, 257-266.

Gao, X., Huete, A. R., Ni, W., \& Miura, T. (2000). Optical-biophysical relationships of vegetation spectra without background contamination. Remote Sensing of Environment, 74, 609-620.

Gilmanov, T. G. Verma, S. B. Sims, P. L. Meyers, T. P. Bradford, J. A Burba, G. G, et al (2003). Gross primary production and light response parameters of four Southern Plains ecosystems estimated using long-term $\mathrm{CO}_{2}$-flux tower measurements. Global Biogeochemical Cycles, 17, 1071. doi:10.1029/2002GB002023.

Göckede, M., Foken, T., Aubinet, M., Banza, J., Bernhofer, C., Bonnefond, J. M., et al. (2008). Quality control of CarboEurope flux data - Part 1: Coupling footprint analyses with flux data quality assessment to evaluate sites in forest ecosystems. Biogeosciences, 5, 433-450.

Gough, C. M., Vogel, C. S., Schmid, H. P., Su, H. -B., \& Curtis, P. S. (2008). Multi-year convergence of biometric and meteorological estimates of forest carbon storage. Agricultural and Forest Meteorology, 148, 158-170.

Gu, L., Meyers, T., Pallardy, S. G., Hanson, P. J., Yang, B., Heuer, M., et al. (2006). Direct and indirect effects of atmospheric conditions and soil moisture on surface energy 
partitioning revealed by a prolonged drought at a temperate forest site. Journal of Geophysical Research, D16102. doi:10.1029/2006JD007161.

Gu, L., Meyers, T., Pallardy, S. G., Hanson, P. J., Yang, B., Heuer, M., et al. (2007). Influences of biomass heat and biochemical energy storages on the land surface fluxes and radiative temperature. Journal of Geophysical Research, D02107. doi:10.1029/2006JD007425.

Hagen, S. C., Braswell, B. H., Linder, E., Frolking, S., Richardson, A. D., \& Hollinger, D. Y. (2006). Statistical uncertainty of eddy-flux based estimates of gross ecosystem carbon exchange at Howland Forest, Maine. Journal of Geophysical Research, 111, D08S03. doi:10.1029/2005JD006154.

Heinsch, F. A., Reeves, M., Votava, P., Kang, S., Milesi, C., Zhao, M. et al. (2003). User's Guide, GPP and NPP (MOD17A2/A3) Products, NASA MODIS Land Algorithms, Version 2.0

Hoblen, B. N. (1986). Characteristics of maximum value composite images from temporal VHRR data. International Journal of Remote Sensing, 7, 1417-1434.

Hollinger, D. Y., Aber, J., Dail, B., Davidson, E. A., Goltz, S. M., Hughes, H., et al. (2004). Spatial and temporal variability in forest-atmosphere $\mathrm{CO}_{2}$ exchange. Global Change Biology, 10, 1689-1706

Hollinger, S. E., Bernacchi, C. J., \& Meyers, T. P. (2005). Carbon budget of mature no-till ecosystem in North Central Region of the United States. Agricultural and Forest Meteorology, 130, 59-69.

Hollinger, D. Y., Goltz, S. M., Davidson, E. A., Lee, J. T., Tu, K., \& Valentine, H. T. (1999). Seasonal patterns and environmental control of carbondioxide and water vapor exchange in an ecotonal boreal forest. GlobalChange Biology, 5, 891-902.

Huang, C., \& Townshend, J. R. G. (2003). A stepwise regression tree for nonlinear approximation: Applications to estimating subpixel land cover. International Journal of Remote Sensing, 24, 75-90.

Huete, A., Didan, K., Miura, T., Rodriguez, E. P., Gao, X., \& Ferreira, L. G. (2002). Overview of the radiometric and biophysical performance of the MODIS vegetation indices. Remote Sensing of Environment, 83, 195-213.

Irvine, J., Law, B. E., \& Hibbard, K. A. (2007). Postfire carbon pools and fluxes in semiarid ponderosa pine in Central Oregon. Global Change Biology, 13, 1748-1760.

Jackson, T. J., Chen, D., Cosh, M., Li, F., Anderson, M., Walthall, C., et al. (2004). Vegetation water content mapping using Landsat data derived normalized difference water index fro corn and soybeans. Remote Sensing Environment, 92, 475-482.

Jenkins, J. P., Richardson, A. D., Braswell, B. H., Ollinger, S. V., Hollinger, D. Y., \& Smith, M. -L. (2007). Refining light-use efficiency calculations for a deciduous forest canopy using simultaneous tower-based carbon flux and radiometric measurements. Agricultural and Forest Meteorology, 143, 64-79.

Law, B. E. (2006). Carbon dynamics in response to climate and disturbance: Recent progress from multiscale measurements and modeling in AmeriFlux. In $S$. Yamamoto (Ed.), Plant responses to air pollution and global change Tokyo, Japan: Springer.

Law, B. E., Sun, O. J., Campbell, J., Tuyl, S. V., \& Thornton, P. E. (2003). Changes in carbon storage and fluxes in a chronosequence of ponderosa pine. Global Change Biology, 9 , $510-524$.

Law, B. E., Turner, D., Campbell, J., Sun, O. J., Van Tuyl, S., Ritts, W. D., et al. (2004). Disturbance and climate effects on carbon stocks and fluxes across Western Oregon USA. Global Change Biology, 10, 1429-1444

Law, B. E., Turner, D., Lefsky, M., Campbell, J., Guzy, M., Sun, O., et al. (2006). Carbon fluxes across regions: Observational constraints at multiple scales. In J. Wu, B. Jones, H. Li, \& O. Loucks (Eds.), Scaling and uncertainty analysis in ecology: Methods and applications (pp. 167-190). USA: Springer.

Lipson, D. A., Wilson, R. F., \& Oechel, W. C. (2005). Effects of elevated atmospheric $\mathrm{CO}_{2}$ on soil microbial biomass, activity, and diversity in a chaparral ecosystem. Applied and Environmental Microbiology, 71, 8573-8580.

Lloyd, J.. \& Farquhar, G. D. (1996). The $\mathrm{CO}_{2}$ dependence of photosynthesis, plant growth responses to elevated atmospheric $\mathrm{CO}_{2}$ concentrations, and their interaction with soil nutrient status: I. General principles and forest ecosystems. Functional Ecology, 10, $4-32$.

Lutes, D. C., Keane, J. F., Caratti, C. H., Key, C. H., Benson, N. C., \& Gangi, L. J. (2004). FIREMON: Fire Effects Monitoring and Inventory System, Vol. RMRS-GTR-164-CD. (pp. 400)Ogden, UT: US Department of Agriculture Forest Service, Rocky Mountain Research Station.

Ma, S., Baldocchi, D. D., Xu, L., \& Hehn, T. (2007). Inter-annual variability in carbon dioxide exchange of an oak/grass savanna and open grassland in California. Agricultural Forest Meteorology, 147, 157-171.

Mäkelä, A., Pulkkinen, M. A., Kolari, P., Largergren, F., Berbigier, P., Lindroth, A., et al. (2008). Developing an empirical model of stand GPP with the LUE approach: Analysis of eddy covariance data at five contrasting confier sites in Europe. Global Change Biology, 14, 92-108.

McGarvey, R. C., Martin, T. A., \& White, T. L. (2004). Integrating within-crown variation in net photosynthesis in loblolly and slash pine families. Tree Physiology, 24, $1209-1220$

Minasny, B., \& McBratney, A. B. (2008). Regression rules as a tool for predicting soil properties from infrared reflectance spectroscopy. Chemometrics and Intelligent Laboratory Systems, 94, 72-79.

Moffat, A. M., Papale, D., Reichstein, M., Hollinger, D. Y., Richardson, A. D., Barr, A. G., et al. (2007). Comprehensive comparison of gap-filling techniques for eddy covariance net carbon fluxes. Agricultural Forest Meteorology, 147, 209-232.

Monson, R. K., Turnipseed, A. A., Sparks, J. P., Harley, P. C., Scott-Denton, L. E., Sparks, K., et al. (2002). Carbon sequestration in a high-elevation, subalpine forest. Global Change Biology, 8, 459-478.

Myneni, R. B., Dong, J., Tucker, C. J., Kaufmann, R. K., Kauppi, P. E., Liski, J., et al. (2001). A large carbon sink in the woody biomass of northern forests. Proceedings of the National Academy of Sciences of the United States of America, 98, 14784-14789.
Myneni, R. B., Hoffman, S., Knyazikhin, Y., Privette, J. L., Glassy, J., Tian, Y., et al. (2002). Global products of vegetation leaf area and fraction absorbed PAR from year one of MODIS data. Remote Sensing of Environment, 83, 214-231.

Noormets, A., Chen, J., \& Crow, T. R. (2007). Age-dependent changes in ecosystem carbon fluxes in managed forests in northern Wisconsin, USA. Ecosystems, 10 187-203.

Noormets, A., Desai, A. R., Cook, B. D., Euskirchen, E. S., Ricciuto, D. M., Davis, K. J., et al (2008). Moisture sensitivity of ecosystem respiration: Comparison of 14 forest ecosystems in the Upper Great Lakes Region, USA. Agricultural and Forest Meteorology, 148, 216-230.

Noormets, A., McNulty, S. G., DeForest, J. L., Sun, G., Li, Q.. \& Chen, J. (2008). Drought during canopy development has lasting effect on annual carbon balance in a deciduous temperate forest. New Phytologist. doi:10.1111/j.1469-8137.2008.02501.x.

Oak Ridge National Laboratory Distributed Active Archive Center (ORNL DAAC) (2006). MODIS subsetted land products, Collection 4. Available on-line (http://www.daac ornl.gov/MODIS/modis.html) from ORNL DAAC, Oak Ridge, Tennessee, U.S.A. Accessed Month 06, 2007.

Oren, R., Ewers, B. E., Todd, P., Phillips, N., \& Katul, G. (1998). Water balance delineates the soil layer in which moisture affects canopy conductance. Ecological Applications, $8,990-1002$

Oren, R., Hsieh, C. -I., Stoy, P., Albertson, J., McCarthy, H. R., Harrell, P., et al. (2006) Estimating the uncertainty in annual net ecosystem carbon exchange: Spatial variation in turbulent fluxes and sampling errors in eddy-covariance measurements. Global Change Biology, 12, 883-896.

Papale, D., \& Valentini, A. (2003). A new assessment of European forests carbon exchange by eddy fluxes and artificial neural network spatialization. Global Change Biology, 9, 525-535.

Pataki, D. E., \& Oren, R. (2003). Species difference in stomatal control of water loss at the canopy scale in a bottomland deciduous forest. Advances in Water Research, 26, $1267-1278$.

Penuelas, J., Gamon, J. A., Griffin, K. L., \& Field, C. B. (1993). Assessing community type, plant biomass, pigment composition, and photosynthetic efficiency of aquatic vegetation from spectral reflectance. Remote Sensing of Environment, 46, 110-118.

Persson, P., Hall-Könyves, K., Sjöström, G., \& Pinzke, S. (1993). NOAA/AVHRR data for crop productivity estimation in Sweden. Advances in Space Research, 13, 111-116.

Potter, C., Klooster, S., Huete, A., \& Genovese, V. (2007). Terrestrial carbon sinks for the United States predicted from MODIS satellite data and ecosystem modeling. Earth Interactions, $11,1-21$

Powell, T. L., Gholz, H. L., Clark, K. L., Starr, G., Cropper, W. P., \& Martin, T. A. (2008) Carbon exchange of a mature, naturally-regenerated pine forest in north Florida. Global Change Biology, 14, 2523-2538. doi:10.1111/j.1365-2486.2008.01675.x.

Prince, S. D., \& Goward, S. N. (1995). Global primary production: A remote sensing approach. Journal of Biogeography, 22, 815-835.

PRISM Climate Group, Oregon State University, http://www.prismclimate.org, created 4 Feb 2004.

Rahman, A. F., Sims, D. A., Cordova, V. D., \& El-Masri, B. Z. (2005). Potential of MODIS EVI and surface temperature for directly estimating per-pixel ecosystem $C$ fluxes. Geophysical Research Letters, 32, L19404. doi:10.1029/2005GL024127.

Ranson, K. J., Daughtry, C. S. T., Biehl, L. L., \& Bauer, M. E. (1985). Sun-view angle effects on reflectance factors of corn canopies. Remote Sensing of Environment, 18, 147-161.

Reichstein, M., Falge, E., Baldocchi, D., Papale, D., Aubinet, M., Berbigier, P., et al. (2005). On the separation of net ecosystem exchange into assimilation and ecosystem respiration: Review and improved algorithm. Global Change Biology, 11, $1424-1439$.

Richardson, A. D., Hollinger, D. Y., Dail, D. B., Lee, J. T., Munger, J. W., \& O'Keefe, J. (2009), Influence of spring phenology on seasonal and annual carbon balance in two contrasting New England forests. Global Change Biology, 29, 321-331.

Richardson, A. D., Mahecha, M. D., Falge, E., Kattge, J., Moffat, A. M., Papale, D., et al. (2008). Statistical properties of random $\mathrm{CO}_{2}$ flux measurement uncertainty inferred from model residuals. Agricultural and Forest Meteorology, 148, 38-50.

Ruimy, A., Jarvis, P. G., Baldocchi, D. D., \& Saugier, B. (1995). $\mathrm{CO}_{2}$ fluxes over plant canopies and solar radiation: A review. Advances in Ecological Research, 26, 1-68.

RuleQuest, 2008. http://www.rulequest.com. Visited on 10/18/2007.

Running, S. W., Baldocchi, D. D., Turner, D. P., Gower, S. T., Bakwin, P. S., \& Hibbard, K. A (1999). A global terrestrial monitoring network integrating tower fluxes, flask sampling, ecosystem modeling and EOS satellite data. Remote Sensing of Environment, $70,108-127$.

Running, S. W., Nemani, R. R., Heinsch, F. A., Zhao, M., Reeves, M., \& Hashimoto, H (2004). A continuous satellite-derived measure of global terrestrial primary production. BioScience, 54, 547-560.

Ryan, M. G., Binkley, D., Fownes, J. H., Giardina, C. P., \& Senock, R. S. (2004). An experimental test of the causes of forest growth decline with stand age. Ecological Monographs, 74, 393-414.

Schmid, H. P. (1994). Source areas for scalars and scalar fluxes. Boundary Layer Meteorology, 67, 293-318.

Schmid, H. P. (2002). Footprint modeling for vegetation atmospheric exchange studies: A review and perspective. Agricultural and Forest Meteorology, 113, 159-183.

Schmid, H. P., Grimmond, C. S. B., Cropley, F., Offerle, B., \& Su, H. B. (2000). Measurements of $\mathrm{CO}_{2}$ and energy fluxes over a mixed hardwood forest in the mid-western United States. Agricultural and Forest Meteorology, 103, 357-374.

Schmidt, K. S., \& Skidmore, A. K. (2003). Spectral discrimination of vegetation types in a coastal wetland. Remote Sensing of Environment, 85, 92-108.

Scott, R. L., Jenerette, G. D., Potts, D. L., \& Huxman, T. E. (2009). Effects of seasonal drought on net carbon dioxide exchange from a woody-plant-encroached semiarid grassland. Journal of Geophysical Research, 114, G04004. doi:10.1029/2008JG000900. 
Sellers, P. J., Randall, D. A., Betts, A. K., Hall, F. G., Berry, J. A., Collatz, G. J., et al. (1997) Modeling the exchanges of energy, water, and carbon between continents and the atmosphere. Science, 275, 502-509.

Shroyer, J. P., Thompson, C., Brown, R., Ohlenbach, P. D., Fjell, D. L., Staggenborg, S., et al. (1996). Kansas crop planting guide. Publication, Vol. L-818. (pp. 2)Manhattan, KS: Kansas State University.

Sims, D. A., Rahman, A. F., Cordova, V. D., Baldocchi, D. D., Flanagan, L. B., Goldstein, A. H., et al. (2005). Midday values of gross $\mathrm{CO}_{2}$ flux and light use efficiency during satellite overpasses can be used to directly estimate eight-day mean flux. Agricultural and Forest Meteorology, 131, 1-12.

Stoy, P. C., Katul, G. G., Siqueira, M. B. S., Juang, J. Y., Novick, K. A., Uebelherr, J. M., et al. (2006). An evaluation of models for partitioning eddy covariance-measured net ecosystem exchange into photosynthesis and respiration. Agricultural and Forest Meteorology, 141, 2-18.

Thompson, J. R. Spies, T. A. \& Ganio, L. M. (2007). Reburn severity in managed and unmanaged vegetation in a large wildfire. Proceedings of the National Academy of Sciences of the United States of America, 104, 10743-10748.

Tucker, C. J., Vanpraet, C. L., Sharman, M. J., \& Van Ittersum, G. (1985). Satellite remote sensing of total herbaceous biomass production in the Senegalese Sahel: 19801984. Remote Sensing of Environment, 17, 233-249.

Urbanski, S., Barford, C., Wofsy, S., Kucharik, C., Pyle, E., Budney, J., et al. (2007). Factors controlling $\mathrm{CO}_{2}$ exchange on timescales from hourly to decadal at Harvard Forest. Journal of Geophysical Research, 112, G02020. doi:10.1029/2006JG000293.

Verma, S. B., Dobermann, A., \& Cassman, K. G. (2005). Annual carbon dioxide exchange in irrigated and rainfed maize-based agroecosystems. Agricultural and Forest Meteorology, 131, 77-96.

Vermote, E.F., Vermeulen, A. (1999). MODIS Algorithm Technical Background Document - Atmospheric Correction Algorithm: Spectral Reflectances (MOD09), Version 4.0. http://modis.gsfc.nasa.gov/data/atbd/atbd_mod08.pdf.

Vermote, E.F., Kotchenova, S.Y. (2008). MOD09 (Surface Reflectance) User's Guide, Version 1.1, March, 2008, http://modis-sr.ltdri.org.

Wan, Z., Zhang, Y., Zhang, Q., \& Li, Z. -L. (2002). Validation of the land-surface temperature products retrieved from Terra Moderate Resolution Imaging Spectroradiometer data. Remote Sensing of Environment, 83, 163-180.

Waring, R. H., \& Franklin, J. F. (1979). Evergreen coniferous forests of the Pacific Northwest. Science, 204, 1380-1386.

Waring, R. H., Landsberg, J. J., \& Williams, M. (1998). Net primary production of forests: A constant fraction of gross primary production? Tree Physiology, 18, 129-134.
Wofsy, S. C., Goulden, M. L., Munger, J. W., Fan, S. -M., Bakwin, P. S., Daube, B. C., et al. (1993). Net exchange of $\mathrm{CO}_{2}$ in a mid-latitude forest. Science, 260, 1314-1317.

Wylie, B. K., Fosnight, E. A., Gilmanov, T. G., Frank, A. B., Morgan, J. A., Haferkamp, M. R., et al. (2007). Adaptive data-driven models for estimating carbon fluxes in the Northern Great Plains. Remote Sensing of Environment, 106, 399-413.

Xiao, J., Zhuang, Q., Baldocchi, D. D., Law, B. E., Richardson, A. D., Chen, J., et al. (2008). Estimation of net ecosystem carbon exchange for the conterminous United States by combining MODIS and AmeriFlux data. Agricultural and Forest Meteorology, 148, 1827-1847. doi:10.1016/j.agrformet.2008.06.015.

Xiao, J., Zhuang, Q., Liang, E., McGuire, A. D., Moody, A., Kicklighter, D. W., et al. (2009). Twentieth-century droughts and their impacts on terrestrial carbon cycling in China. Earth Interactions, 13(Paper No. 10), 1-31. doi:10.1175/2009EI275.1.

Xu, L., \& Baldocchi, D. D. (2004). Seasonal variation in carbon dioxide exchange over a Mediterranean annual grassland in California. Agricultural and Forest Meteorology, 123, 79-96.

Yang, L., Huang, C., Homer, C., Wylie, B. K., \& Coan, M. J. (2003). An approach for mapping large-area impervious surfaces: Synergistic use of Landsat-7 ETM+ and high spatial resolution imagery. Canadian Journal of Remote Sensing, 29, 230-240.

Yang, F., Ichii, K., White, M. A., Hashimoto, H., Michaelis, A. R., Votava, P., et al. (2007). Developing a continental-scale measure of gross primary production by combining MODIS and AmeriFlux data through support machine approach. Remote Sensing of Environment, 110, 109-122.

Zhang, L., Wylie, B., Loveland, T., Fosnight, E., Tieszen, L. L., Ji, L., et al. (2007). Evaluation and comparison of gross primary production estimates for the Northern Great Plains grasslands. Remote Sensing of Environment, 106, 173-189.

Zhang, Y., Yu, Q., Jiang, J., \& Tang, Y. (2008). Calibration of Terra/MODIS gross primary production over an irrigated cropland on the North China Plain and an alpine meadow on the Tibetan Plateau. Global Change Biology, 14, 757-767.

Zhao, M. Heinsch, F. A. Nemani, R. R. \& Running S. W. (2005). Improvements of the MODIS terrestrial gross and net primary production global data set. Remote Sensing of Environment, 95, 164-175.

Zhao, M., Running, S. W., \& Nemani, R. R. (2006). Sensitivity of moderate resolution imaging spectroradiometer (MODIS) terrestrial primary production to the accuracy of meteorological reanalyses. Journal of Geophysical Research, 111, G01002. doi:10.1029/2004JG000004 